\title{
The geochemical effects of olivine slurry replenishment and dolostone assimilation in the plumbing system of the Franklin Large Igneous Province, Victoria Island, Arctic Canada
}

\author{
Ben Hayes · C. Johan Lissenberg • Jean H. Bédard • \\ Charlie Beard
}

Received: 28 August 2014 / Accepted: 28 January 2015 / Published online: 13 February 2015

(C) The Author(s) 2015. This article is published with open access at Springerlink.com

\begin{abstract}
The Neoproterozoic ( 723-716 Ma) Franklin Large Igneous Province exposed on Victoria Island in the Canadian Arctic is comprised of a sill-dominated magma plumbing system overlain by the coeval Natkusiak flood basalts. We have investigated three sections, separated by a total of $>50 \mathrm{~km}$ of distance, of a sill (the Fort Collinson Sill Complex) emplaced just above a prominent sedimentary marker unit. The sill is characterized by a basal olivineenriched layer (OZ: up to $55 \%$ olivine) and an upper gabbroic unit. The observed diversity of olivine compositions in the $\mathrm{OZ}$ implies that bulk-rock $\mathrm{MgO}$ versus $\mathrm{FeO}$ arrays reflect accumulation of a heterogeneous olivine crystal cargo. We suggest that the $\mathrm{OZ}$ was formed as a late olivine slurry replenishment in a partially crystallized gabbroic sill, propagating for over $50 \mathrm{~km}$ along strike. This interpretation is consistent with $\mathrm{Pb}$-isotope data, which show that at least three geochemically distinct magmas were emplaced into the Fort Collinson Sill Complex. The OZs exhibit a gradual
\end{abstract}

Communicated by Othmar Muntener.

Electronic supplementary material The online version of this article (doi:10.1007/s00410-015-1117-8) contains supplementary material, which is available to authorized users.

B. Hayes $(\bowtie) \cdot$ C. J. Lissenberg

School of Earth and Ocean Sciences, Cardiff University,

Park Place, Cardiff CF10 3AT, UK

e-mail: hayesb@cf.ac.uk

J. H. Bédard

Geological Survey of Canada, 490 de la Couronne, Québec City, QC G1K 9A9, Canada

C. Beard

Department of Earth and Planetary Sciences, McGill University, 3450 University Street, Montreal, QC H3A 0E8, Canada westward evolution toward more Fe-rich bulk compositions. This is best explained by progressive mixing of the replenishing olivine slurry with a resident gabbroic mush during westward flow. $\mathrm{Pb}$-isotopic signatures suggest that magmas near the inferred conduit feeder assimilated small amounts $(<10 \%)$ of dolostone country rock, which may have locally buffered olivine compositions to high-Fo contents.

Keywords Contamination - Differentiation - Franklin . Olivine $\cdot$ Slurry $\cdot$ Sills

\section{Introduction}

To understand the geochemical evolution of basalts, we need to constrain the processes active in the associated magmatic plumbing system. Sill-dominated plumbing systems are prominent in Proterozoic and Phanerozoic continental flood basalt provinces (Baragar 1976; Francis and Walker 1986; Hawkesworth et al. 1995; Chevallier and Woodford 1999; Bédard et al. 2007), oceanic crust formed by seafloor-spreading (Bédard 1991; Lissenberg et al. 2004), oceanic plateau crust (Kerr et al. 1998), and Archean greenstones (Bédard et al. 2009). Documenting lateral changes in bulk-rock and mineral chemistry in the constituent sills of such basaltic plumbing systems would shed light on the mechanisms of magma emplacement in the crust, of magma interaction with host rocks, on igneous differentiation processes, and may enable the reconstruction of magma flow directions (Marsh 2004). In addition to constraining fundamental properties of magmatic systems, this type of information is an important element in the search for Noril'sk-type Ni-Cu-PGE sulfide deposits (Naldrett 1992). 
Separation of crystals from melt in magma chambers is frequently assumed to be responsible for the observed geochemical diversity of lavas (Bowen 1928) and also plays a role in the development of layering in fossil magma chambers (Wager and Deer 1939; Irvine 1980, 1987; Naslund and McBirney 1996). Recent discussions have emphasized the importance of remobilization of previously deposited crystal cumulates or crystal slurries, and associated consequences for the magmatic evolution of plutonic systems (Marsh 2013; Neave et al. 2013; Leuthold et al. 2014). It has also been proposed that the abundant phenocrysts seen in some basalts are remobilized cumulates that were flushed out of underlying feeder systems (Larrea et al. 2012; Passmore et al. 2012). Examples of crystal slurry emplacement have been documented in the Ferrar sills of Antarctica (Bédard et al. 2007); the Shiant Isles sills in NW Scotland (Gibb and Henderson 2006); and the Franklin sills on Victoria Island (Hayes et al. 2015). The emplacement of crystal slurries is also pertinent for the construction of large layered intrusions such as the Bushveld Complex (Mondal and Mathez 2007; Roelofse and Ashwal 2012; Wilson 2012). Slurry remobilization is also implicated in the genesis of anomalous concentrations of immiscible sulfide liquids observed in some $\mathrm{Ni}-\mathrm{Cu}-\mathrm{PGE}$ deposits (Naldrett 1992).

An additional factor that can affect melt and crystal evolution is the assimilation of (and reaction with) country rocks. It is widely accepted that mantle-derived melts may undergo modification of their isotopic signatures as a result of crustal assimilation, e.g., Hildreth and Moorbath (1988). Assimilation of carbonate rocks in particular may impact on the liquid line of descent (LLD) of magma by buffering melt $\mathrm{Mg} / \mathrm{Fe}$ ratios and preferentially stabilizing clinopyroxene on the liquidus (Di Rocco et al. 2012; Mollo and Vona 2014). The impacts of carbonate assimilation have been demonstrated for Merapi Volcano (Chadwick et al. 2007; Troll et al. 2013) and the Colli Albani volcanic district (Gaeta et al. 2009; Di Rocco et al. 2012), but are not as well documented in tholeiitic systems. Assimilation of carbonate rocks by magma can potentially release significant volumes of $\mathrm{CO}_{2}$ (Iacono Marziano et al. 2007), which may perturb global climate. $\mathrm{CO}_{2}$ excursions in the geological record have been correlated with the formation of Large Igneous Provinces (LIPs) (Wignall 2001).

The well-preserved and exposed Neoproterozoic Franklin LIP on Victoria Island provides a unique natural laboratory to address many of these issues. The Franklin LIP has a sill-dominated magmatic plumbing system with local fault-mediated shifts in emplacement level that facilitated magma transgression (Bédard et al. 2012). Franklin sills were emplaced primarily into limestones and dolostones, and calc-silicate skarns that formed by magma-carbonate interaction are locally prominent (Nabelek et al. 2013).
Hayes et al. (2015) documented the development of firstorder modal layering in a composite Franklin sill as a result of two magmatic pulses. They proposed that the basal olivine-enriched layer of the $\sim 21$-m-thick Lower Pyramid Sill (LPS) represents a late olivine slurry replenishment into a resident gabbroic mush. Here, we present data from two other localities situated north of Minto Inlet on Victoria Island (Fig. 1) that we believe represent sections through coeval and possibly correlative sills. The P-sill (PS) is located $\sim 20 \mathrm{~km}$ to the ENE of the LPS, while the West Uhuk Sill (WUS) is another $\sim 30 \mathrm{~km}$ to the ENE (Fig. 1). Both have olivine-enriched bases and were emplaced at the same stratigraphic level, just above the Fort Collinson Formation marker unit. The WUS is adjacent to a prominent fault-guided magma upflow zone known as the Uhuk Massif (UM: described in Bédard et al. (2012)), which preserves calc-silicate reaction facies at some intrusive contacts (Nabelek et al. 2013). These three olivine-enriched sills (WUS, PS, and LPS) are collectively termed the Fort Collinson Sill Complex (FCSC). We will compare sections through them and document how bulk-rock compositions, mineral chemistry, and isotopic compositions vary along strike.

In this contribution, we propose that the FCSC records a regional scale $(>50 \mathrm{~km})$ olivine slurry replenishment event in a previously emplaced sill. The along-strike changes in composition recorded in the FCSC provide constraints on the geochemical and textural impacts of cumulate remobilization and slurry emplacement. We also discuss how small amounts of dolostone assimilation could have increased the $\mathrm{Mg} / \mathrm{Fe}$ ratio of the magma and buffered the Fo content of equilibrium olivine in some parts of the FCSC.

\section{Regional geology}

\section{The Franklin sills}

The Franklin LIP is thought to be related to breakup of Rodinia, and geochemically equivalent rocks have been recognized across the Canadian Arctic, to Greenland and Siberia (Heaman et al. 1992; Rainbird 1993; Pehrsson and Buchan 1999; Shellnutt et al. 2004; Ernst et al. 2008; Ariskin et al. 2009; Denyszyn et al. 2009). The Franklin intrusions are dated between 723 and $716 \mathrm{Ma}$, corresponding to the early stages of the Neoproterozoic Sturtian glaciation (Heaman et al. 1992; Macdonald et al. 2010). Franklin-aged rocks are well preserved in the Minto Inlier of Victoria Island (Fig. 1), where they are hosted by the Shaler Supergroup; a sequence of Neoproterozoic carbonates and subordinate clastic and evaporitic sedimentary rocks that were deposited in the Amundsen Basin (Jefferson 1977; Rainbird et al. 1994, 1996). Shaler rocks are intruded by $\sim 20$ gabbroic 
Fig. 1 Geological map of the Minto Inlier on Victoria Island adapted from Bédard et al. (2012), with the olivineenriched sills of the FCSC labeled. WUS West Uhuk Sill, $P S$ P-sill, LPS Lower Pyramid Sill. The inferred location of the feeder system to the FCSC is labeled UM (Uhuk Massif), which corresponds to a NNW-trending Neoproterozoic fault. The locations of other olivine-enriched sills, including Kat's, Dick's, and Uwe's are also shown

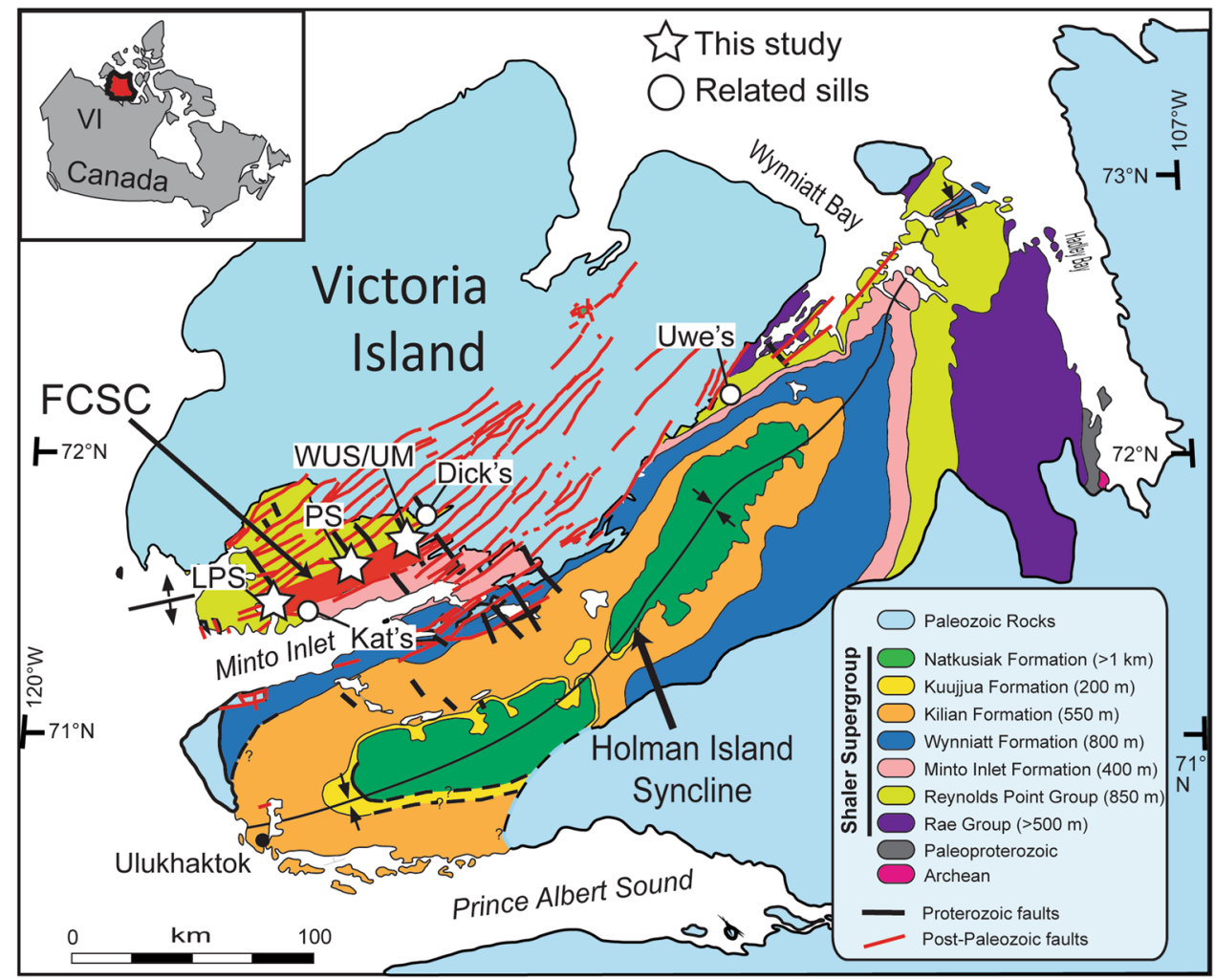

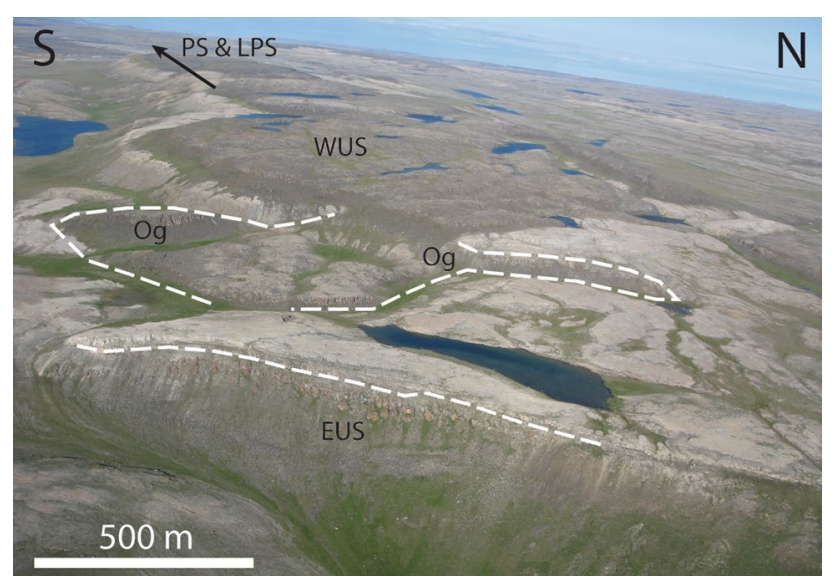

Fig. 2 Field photograph of the UM feeder system (looking west). The olivine-enriched East Uhuk Sill (EUS) jogs up-section into the WUS, with minor olivine-enriched $(\mathrm{Og})$ transgressive sills between the two main sills. The WUS extends toward the west, to the PS and LPS

sills, which are generally $20-60 \mathrm{~m}$ in thickness (Jefferson et al. 1994; Hulbert et al. 2005). Good exposure allows some of the sills to be traced for tens of kilometers along strike (Fig. 2). In places, sills are connected to gabbroic feeder-dyke networks that generally trend NW-SE (Bédard et al. 2012). The Shaler Supergroup rocks are overlain by the Natkusiak flood basalts, the extrusive component of the Franklin LIP (Baragar 1976). Two main magma populations are identified in the Franklin LIP. Light-rare-earth element
(LREE)-enriched magmas form a thin basal lava sequence (Williamson et al. 2013). These are succeeded by voluminous tholeiitic sheet flows that have lower LREE/HREE (Dostal et al. 1986). Crosscutting relationships and diagnostic geochemical signatures allow correlation between the sills and lavas. Sills that formed from LREE-enriched magmas (corresponding to the basal lavas) are largely restricted to the lower ( 2-4 km depth) part of the stratigraphy. We refer to these as Type-1 sills. Many have olivine cumulateenriched layers near their base, including the sills constituting the FCSC. Younger, Type-2 intrusions, which have doleritic or clinopyroxene-plagioclase-phyric textures, occur throughout the Shaler Supergroup and are geochemically similar to the younger sheet flow unit of the Natkusiak flood basalts (Beard et al. submitted).

\section{Fort Collinson Sill Complex}

The FCSC, comprising the WUS, the PS, and the LPS, outcrops in the Collingwood Hills region of the Minto Inlier, just north of Minto Inlet (Fig. 1). The FCSC was emplaced $\sim 3 \mathrm{~km}$ stratigraphically beneath the coeval Natkusiak flood basalts. Previous work has documented the field relationships at the Uhuk Massif (Bédard et al. 2012), showing that the Uhuk Massif (UM) is a magma upflow zone that extends toward the west as a conformable silllike body, the WUS (Fig. 2). The WUS was emplaced into the dolostone-dominated Jago Bay Formation, only $\sim 10 \mathrm{~m}$ 
above the contact with the underlying Fort Collinson Formation, which is dominated by quartz arenites. The WUS is $\sim 40 \mathrm{~m}$ thick, has sharp chilled lower and upper contacts, and contains a $\sim 12-\mathrm{m}$-thick olivine-enriched layer in its lower section that we refer to as the Olivine Zone (OZ). About $30 \mathrm{~km}$ to the WSW, we sampled a section through another olivine-rich sill (PS) that is located at exactly the same stratigraphic level as the WUS. No chilled margins are exposed at the PS, which has a slightly thinner OZ ( $\sim 10 \mathrm{~m}$ thick) in comparison with the WUS. About $20 \mathrm{~km}$ to the WSW of the PS is the 21 -m-thick LPS, which, again, is at the same stratigraphic position as the WUS and PS. Both chilled margins are exposed at the LPS, which has an $\mathrm{OZ}$ that is $\sim 7 \mathrm{~m}$ thick. The petrology and mineral chemistry of the LPS were described in detail by Hayes et al. (2015) who argued, on the basis of textural and mineral-chemical data, that the LPS OZ is a hybrid rock that formed by mixing between a late olivine slurry and a resident gabbroic mush.

\section{Analytical methods}

We analyzed 71 samples from the FCSC ( 30 from WUS and adjoining UM, 15 from PS, and 26 from LPS) for bulk-rock major and trace elements at the INRS-ETE laboratories in Québec City, Canada. Some of the WUS and UM data originate from previous field campaigns by the Geological Survey of Canada (Bédard et al. in prep). Rock samples were initially trimmed and then reduced with a steel jaw crusher before being powdered with a planetary agate mortar. Sample fusion was operated on a Claisse fluxer using $\mathrm{LiBO}_{2}$ and $\mathrm{LiBr}$. The $\mathrm{HNO}_{3}-\mathrm{HCl}$ sinter technique was employed to circumvent potential problems associated with high field-strength elements (HFSE) and rare-earth elements (REEs) in refractory minerals. The major elements and $\mathrm{Ba}, \mathrm{Sr}, \mathrm{Sc}, \mathrm{V}, \mathrm{Co}, \mathrm{Cr}, \mathrm{Cu}, \mathrm{Ni}$, and $\mathrm{Zn}$ compositions were determined by inductively coupled plasma-atomic emission spectrometry (ICP-OES). Trace elements were determined by inductively coupled plasma-mass spectrometry (ICP-MS) using a method similar to that described by Varfalvy et al. (1997). Full details of the detection limits and the accuracy and precision of the data are summarized in Leclerc et al. (2011). A suite of samples from the LPS were analyzed using the ICP laboratories at Cardiff University in the United Kingdom. The samples were prepared into solutions for ICP-MS and ICP-OES analyses using the lithium metaborate fusion method described in McDonald and Viljoen (2006). All bulk-rock chemical data are available in Appendix Table 1 in ESM.

In situ mineral chemical analyses were performed using a Cameca SX-100 electron microprobe at the University of Laval in Québec City, Canada. The probe was fitted with five wavelength-dispersive spectrometers. Accelerating voltage was $15 \mathrm{kV}$, beam current was $20 \mathrm{nA}$, and olivine was analyzed with a focused beam $(1 \mu \mathrm{m}$ diameter $)$ with counting times of $20 \mathrm{~s}$ on peak levels and $10 \mathrm{~s}$ on background levels. The full olivine dataset for the WUS and PS is provided in Appendix Table 2 in ESM. The LPS olivine dataset and the electron microprobe method are provided in Hayes et al. (2015).

Samples selected for $\mathrm{Pb}$-isotope analyses were prepared at the Pacific Centre for Isotopic and Geochemical Research (PCIGR) at the University of British Columbia, Vancouver. The dataset and details of methods used can be found in Beard et al. (submitted). Samples selected for S-isotope analyses were prepared and analyzed at McGill University, Montréal. The dataset are included in Appendix Table 3 in ESM, and the details of methods can be found in Hryciuk et al. (submitted).

\section{Results}

\section{Petrography}

The sills constituting the FCSC exhibit near-identical internal stratigraphies, albeit with differences in layer thicknesses. From bottom to top, they have an olivine-phyric ( 5 \%) Lower Chilled Margin (LCM); an olivine-phyric $(\sim 10 \%)$ Lower Border Zone (LBZ); an Olivine Zone (OZ) composed of olivine-melagabbro to feldspathic peridotite with olivine modes up to $\sim 55 \%$; a clinopyroxene-rich cumulate gabbro zone (CPZ), which is most prominent at the LPS; a doleritic gabbro zone (DZ) comprised of sub-ophitic clinopyroxene and plagioclase with a minor $(<10 \%)$ cumulate component; an aphyric Upper Border Zone (UBZ); an olivine-phyric ( $5 \%$ ) Upper Chilled Margin (UCM). The key features of each layer are summarized in an idealized FCSC stratigraphic log (Fig. 3). We will now describe the key features of each layer of the FCSC following the nomenclature of Irvine (1982) and then discuss along-strike sill-to-sill variations.

Where it is visible, the thin $(\sim 5 \mathrm{~cm})$ LCM contains $5 \%$ euhedral $(0.5-2 \mathrm{~mm})$ olivine phenocrysts in a very-finegrained groundmass $(0.1 \mathrm{~mm})$ of plagioclase and clinopyroxene dendrites. Small chromite microphenocrysts occur both as inclusions in olivine and in the groundmass. In the WUS LCM, hopper olivine is also present (Fig. 4a). The UCM is exposed at both the LPS and WUS and also contains $5 \%$ olivine phenocrysts (or its pseudomorphs) in a very-fine-grained groundmass $(0.1 \mathrm{~mm})$. Amygdules (1-2 mm) filled with secondary chlorite, biotite, and quartz are present in the UCM.

The LPS LCM grades up into a $\sim 1 \mathrm{~m}$-thick LBZ, where euhedral $(1-2 \mathrm{~mm})$ olivine phenocrysts are embedded in 


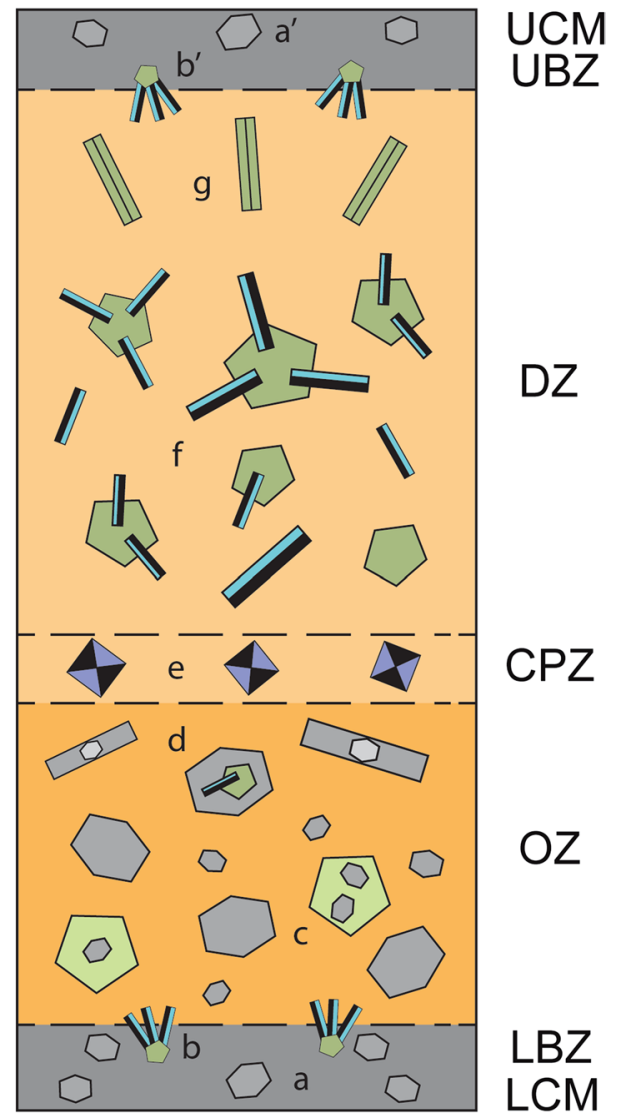

Fig. 3 A schematic log through the FCSC, showing key features of each layer. Both Lower and Upper Chilled Margins (LCM and $\mathrm{UCM}$, respectively) contain olivine phenocrysts $\left(a, a^{\prime} \sim 5 \%\right)$. The chilled margins grade into Lower and Upper Border Zones (LBZ and UBZ, respectively) characterized by plagioclase and clinopyroxene dendrites $\left(b, b^{\prime}\right.$ with local nucleation on the surfaces of olivine phenocrysts). The olivine zone (OZ) is characterized by high olivine modes (up to $55 \%$ ) with primitive olivine primocrysts, pyroxenepoikilitic textures $(c)$, and anhedral olivine-clinopyroxene textures. The $\mathrm{OZ}$ also contains hopper olivines $(d)$. The clinopyroxene zone (CPZ) is characterized by abundant (40-50 \%) sector-zoned clinopyroxene in an olivine-poor (5-10\%) gabbroic matrix $(e)$. The doleritic zone (DZ) consists of sub-ophitic plagioclase and clinopyroxene $(f)$ with minor olivine, sometimes pseudomorphed by orthopyroxene. The top part of the DZ is characterized by acicular pyroxenes $(g)$ and an increase in late-stage accessory phases (quartz, alkali feldspar, hornblende, and biotite)

a matrix composed of plagioclase and clinopyroxene dendrites (1-2 mm). The LBZ at the WUS and PS is generally similar, although the slightly thicker $(\sim 5 \mathrm{~m})$ WUS LBZ also contains olivine with hopper morphologies (Fig. 4b). At the PS and WUS, the dendrite-textured basal LBZ grades up into an upper LBZ facies with a gabbroic-textured groundmass (Fig. 4c). Some olivine primocrysts appear to have been fractured and veined by groundmass plagioclase. Clinopyroxene oikocrysts contain inclusions of olivine, chromite, and euhedral plagioclase laths. Minor groundmass orthopyroxene is also observed.
The LPS UCM grades down to an UBZ that is free of olivine phenocrysts, and which is composed of plagioclase and clinopyroxene dendrites. Hayes et al. (2015) suggested that the absence of phenocrysts was due to crystal settling of olivine, such that the propagating upper crystallization front was no longer able to capture fastsettling phenocrysts after about $10-15 \mathrm{~cm}$ of growth. The WUS has a very thin UBZ, whereas the uppermost facies are missing from the PS as a result of erosion. The UBZ at the WUS grades down rapidly into varitextured DZ gabbros, some markedly pegmatitic with acicular pyroxene morphologies.

The LPS LBZ grades up into a $\sim 7$-m-thick OZ composed of olivine orthocumulate melagabbro to feldspathic peridotite with $40-55 \%$ modal olivine. The OZ is slightly thicker $(\sim 9-10 \mathrm{~m})$ at the PS and thicker again $(\sim 12 \mathrm{~m})$ at the WUS. Hayes et al. (2015) subdivided the LPS OZ into lower, middle, and upper facies, based on olivine morphologies. The LPS lower OZ contains euhedral (1-2 mm) olivine primocrysts and finer-grained $(0.5-1 \mathrm{~mm})$ olivine that are enveloped by clinopyroxene oikocrysts and interstitial plagioclase. The LPS middle OZ has fewer olivine primocrysts and is dominated by anhedral olivine that is intergrown with clinopyroxene (Fig. 4d). The LPS upper OZ mostly contains hopper olivine (Fig. 4e), with subordinate primocrystic and groundmass olivine. Upper OZ clinopyroxene is commonly euhedral and does not contain olivine chadacrysts.

In the PS and WUS, the divisions into lower OZ, middle OZ, and upper OZ are less clear than at the LPS. In the WUS OZ, hopper olivine can be seen at various levels rather than being restricted to the upper OZ (Fig. 4f). Near the base of the PS and WUS OZ, clinopyroxene occurs both as oikocrysts (Fig. 4g) and as euhedral "cumulus" grains, some with internal "fairy rings" of chromite microphenocrysts. Higher in the PS and WUS OZ, subordinate orthopyroxene occurs as oikocrysts, as euhedral prisms or is intergrown with clinopyroxene. Some olivine inclusions in clinopyroxene oikocrysts have hopper shapes and contain clinopyroxene inclusions (Fig. 4h). Plagioclase occurs as subhedral inclusions in clinopyroxene oikocrysts, as interstitial grains and as fine groundmass laths.

Overlying the LPS OZ is a thin $(\sim 1 \mathrm{~m}) \mathrm{CPZ}$, which is dominated by euhedral sector-zoned clinopyroxene (40-50 \%). Equivalents of the CPZ were observed at the PS interlayered with olivine-rich cumulates. CPZtype rocks were not identified in our section through the poorly exposed OZ/DZ transition at the WUS. In the PS, the euhedral sector-zoned clinopyroxene commonly has sieved internal zones and may have alternating normal and reversed zones (in terms of $\mathrm{Mg \# )}$ ). The matrix of the PS CPZ preserves hopper olivine that is cemented by plagioclase. 
Fig. 4 Photomicrographs (all in crossed-nicols) of olivine morphologies and textural relationships in the FCSC. a The olivine-phyric WUS LCM with the lower contact with the Jago Bay Formation visible. Olivine phenocrysts (Olph) and hopper olivines (Hol) are shown, residing in a very-fine-grained groundmass (Gm). b The WUS LBZ contains both phenocrystic and hopper olivine that reside in a fine-grained matrix of clinopyroxene (Cpx) and plagioclase dendrites (Pld). c The PS LBZ showing a euhedral olivine phenocryst residing in a dendritic matrix. d The LPS OZ (specifically the middle OZ) showing both olivine primocrysts and amoeboid olivines that are overgrown by clinopyroxene. e The LPS OZ (specifically the upper OZ) showing hopper olivines that are intergrown with interstitial plagioclase (Plg). f The WUS OZ showing hopper olivine (Hol), olivine chadacrysts $(\mathrm{Olc})$ enclosed in poikilitic clinopyroxene (Pcpx) and groundmass olivines $(\mathrm{Olg})$ residing in interstitial plagioclase. $\mathbf{g}$ The WUS OZ showing euhedral olivine primocrysts (Olpr) and a coarse poikilitic clinopyroxene enclosing abundant olivine chadacrysts. $\mathbf{h}$ The PS OZ showing a hopper olivine that is overgrown by clinopyroxene
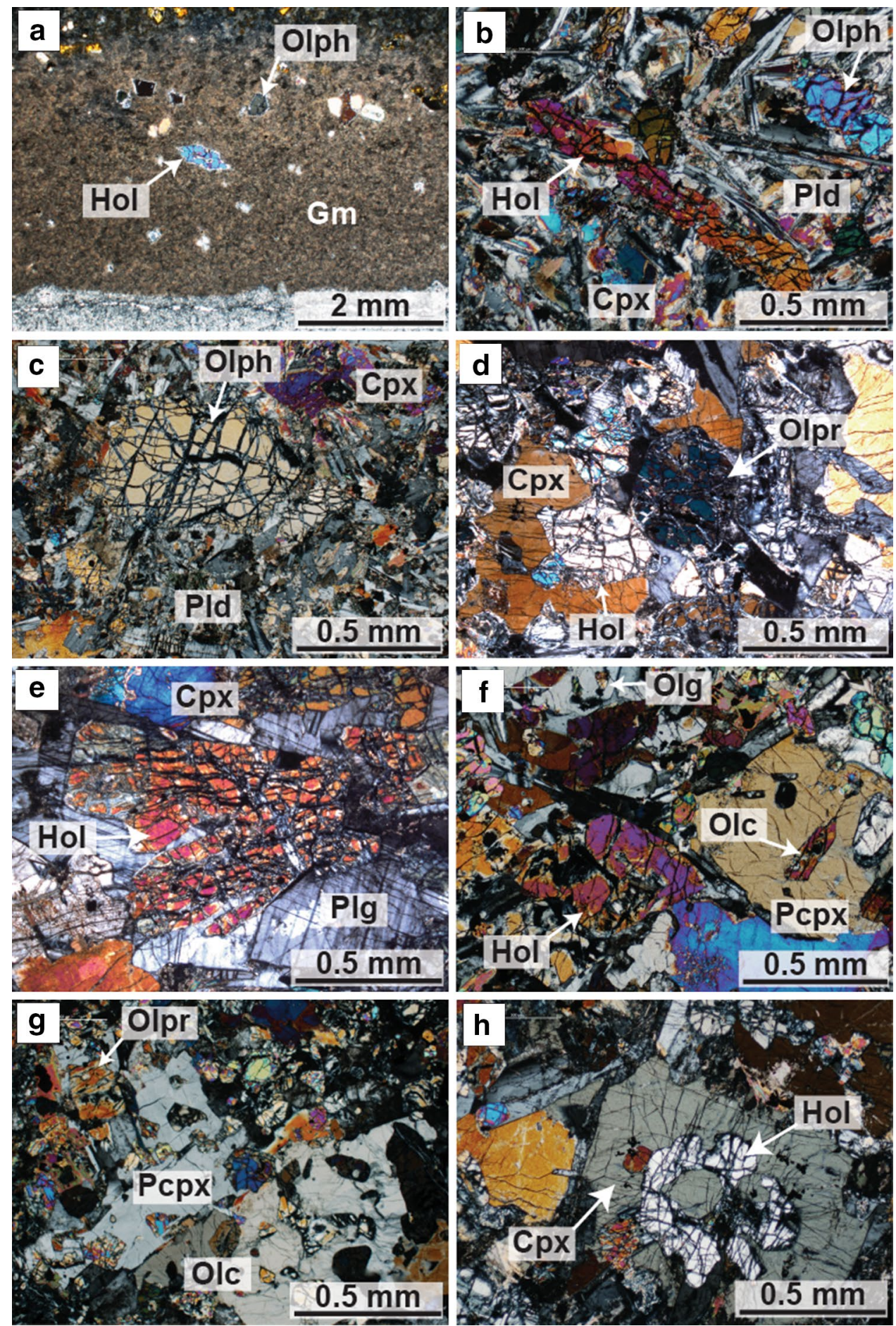

Above the LPS CPZ is a 9- to 10-m-thick DZ, which mostly consists of sub-ophitic clinopyroxene and plagioclase. Orthopyroxene $(\sim 10 \%)$ in the LPS DZ may be pseudomorphous after olivine. The habit of clinopyroxene changes gradually from blocky prismatic crystals at the base of the LPS DZ to acicular elongated prisms in the upper LPS DZ. The PS DZ and WUS DZ show a general similarity to the LPS DZ, but with some differences. At the WUS, the DZ is markedly thicker $(\sim 27 \mathrm{~m})$ than at the LPS. The basal DZ at the WUS and PS contains $10 \%$ euhedral olivine (1-3 mm) in a gabbroic matrix (1-2 mm) with only minor $\mathrm{Fe}$-Ti oxides (1-2 \%) and granophyric patches. Some clinopyroxene grains are equant to euhedral, with optically distinct cores reminiscent of CPZ clinopyroxene. Plagioclase is generally anhedral, with a few coarser (1-2 mm) euhedral (cumulus?) laths that may have spongy internal zones. In the PS, this 
Table 1 Selected major-element compositions of the rocks comprising the FCSC

\begin{tabular}{|c|c|c|c|c|c|c|c|c|c|c|c|}
\hline Sill & LPS & LPS & LPS & LPS & PS & PS & WUS & WUS & WUS & WUS & FCSC \\
\hline Zone & $\mathrm{LCZ}$ & OZ (LOZ) & $\mathrm{OZ}(\mathrm{MOZ})$ & OZ (UOZ) & $\mathrm{OZ}$ & $\mathrm{OZ}$ & $\mathrm{LCZ}$ & $\mathrm{OZ}$ & $\mathrm{OZ}$ & $\mathrm{OZ}$ & AV CHILL \\
\hline Sample ID & JB327B1 & BH166A5 & BH167A2 & BH311B3 & JB367E1 & JB368A1 & AW54B1 & $0723 \mathrm{~A} 003$ & $0723 \mathrm{~A} 015$ & $0726 \mathrm{~A} 003$ & \\
\hline $\mathrm{SiO}_{2}$ & 48.278 & 44.491 & 42.389 & 43.952 & 44.798 & 43.495 & 48.780 & 44.460 & 42.710 & 44.780 & 48.057 \\
\hline $\mathrm{TiO}_{2}$ & 1.023 & 0.733 & 0.576 & 0.637 & 0.677 & 0.616 & 0.970 & 0.620 & 0.500 & 0.620 & 0.990 \\
\hline $\mathrm{Al}_{2} \mathrm{O}_{3}$ & 12.763 & 8.997 & 6.683 & 7.897 & 8.673 & 8.028 & 12.937 & 8.550 & 6.950 & 8.440 & 12.918 \\
\hline $\mathrm{Fe}_{2} \mathrm{O}_{3} \mathrm{~T}$ & 11.135 & 13.461 & 14.832 & 14.431 & 13.075 & 13.238 & 12.202 & 12.350 & 12.720 & 11.670 & 11.665 \\
\hline $\mathrm{FeO} *$ & 10.010 & 12.101 & 13.334 & 12.973 & 11.754 & 11.901 & 10.970 & 11.103 & 11.435 & 10.491 & 10.487 \\
\hline $\mathrm{MnO}$ & 0.147 & 0.197 & 0.204 & 0.202 & 0.185 & 0.186 & 0.186 & 0.170 & 0.170 & 0.150 & 0.160 \\
\hline $\mathrm{MgO}$ & 10.743 & 19.950 & 23.519 & 20.523 & 20.759 & 23.150 & 10.898 & 20.710 & 23.490 & 20.180 & 10.328 \\
\hline $\mathrm{CaO}$ & 12.255 & 8.811 & 6.473 & 8.355 & 7.455 & 7.081 & 11.461 & 7.130 & 5.750 & 8.030 & 11.170 \\
\hline $\mathrm{Na}_{2} \mathrm{O}$ & 1.526 & 0.971 & 0.311 & 0.781 & 0.872 & 0.645 & 1.490 & 0.920 & 0.670 & 0.910 & 1.891 \\
\hline $\mathrm{K}_{2} \mathrm{O}$ & 0.557 & 0.414 & 0.275 & 0.260 & 0.368 & 0.314 & 0.565 & 0.420 & 0.260 & 0.320 & 1.026 \\
\hline $\mathrm{P}_{2} \mathrm{O}_{5}$ & 0.087 & 0.063 & 0.052 & 0.052 & 0.049 & 0.045 & 0.085 & 0.060 & 0.040 & 0.040 & 0.080 \\
\hline LOI & 1.443 & 1.925 & 5.776 & 3.085 & 2.633 & 3.470 & 0.612 & 4.200 & 6.200 & 4.400 & 1.639 \\
\hline Total & 100.254 & 100.011 & 101.090 & 100.174 & 99.814 & 100.756 & 100.457 & 99.980 & 99.860 & 99.860 & 101.561 \\
\hline
\end{tabular}

Example OZs from the LPS, PS, WUS are shown, as well as the LCMs of the LPS and WUS. The average FCSC chill composition is also shown. See Appendix Table 1 in ESM for the full dataset

basal olivine-bearing DZ facies is thin and grades up rapidly into a varitextured doleritic gabbro that contains abundant $\mathrm{Fe}-\mathrm{Ti}$ oxides and shows marked variations in grain size through the development of pegmatoidal patches. The basal WUS DZ described above is succeeded by a thick, doleritictextured gabbro with acicular clinopyroxene habits. Approximately $12 \mathrm{~m}$ below the upper contact, the proportion of $\mathrm{Fe}-$ Ti oxides and sulfides in this gabbro increases markedly (to $\sim 10 \%$ ), as does the amount of granophyre (to $\sim 10 \%$ ) and hornblende $(\sim 5 \%)$. The uppermost portions of the WUS DZ resemble the upper varitextured gabbroic facies seen at the PS, with abundant pegmatoidal patches and acicular pyroxene habits. We interpreted the increase in these accessory phases in the upper DZ at the LPS to represent an evolved residue (sandwich horizon) that formed by in situ fractional crystallization (Hayes et al. 2015).

\section{Bulk-rock chemistry}

The chilled margin compositions of the WUS and LPS are very similar (10.9 vs. $10.7 \mathrm{wt} \% \mathrm{MgO}$, respectively: Table 1). Meter-scale dykes emplaced near the contacts of the UM also have similar compositions (Appendix Table 1 in ESM). We calculated an average FCSC chill composition of $10.3 \mathrm{wt} \% \mathrm{MgO}$ (Table 1) from 10 samples (chills, thin sills, and dykes). This chill composition was used by Hayes et al. (2015) as a starting composition for PELE (Boudreau 1999) fractional crystallization modeling, which will be used to anchor some of the models in the discussion section below.

Many of the OZ rocks from the FCSC show MgOenrichment and $\mathrm{Al}_{2} \mathrm{O}_{3}$-depletion trends, indicating that they contain cumulus olivine (Table 1 ). The $\mathrm{OZ}$ rocks have $\mathrm{MgO}$ contents between 18 and $27 \mathrm{wt} \%, \mathrm{Al}_{2} \mathrm{O}_{3}$ between 6 and $10 \mathrm{wt} \%$, and Ni contents up to $720 \mathrm{ppm}$ (Table 1). The CPZ rocks have high $\mathrm{CaO}$ contents, with values between 12 and $14 \mathrm{wt} \%$, and high $\mathrm{Cr}$ and Sc (1,500 and $52 \mathrm{ppm}$, respectively), indicating a cumulate clinopyroxene component. The major-element chemistry of DZ rocks is very similar in all three sections of the FCSC, with $\mathrm{MgO}$ contents ranging between 6 and $10 \mathrm{wt} \%$. FCSC DZ rocks show clear trends of increasing $\mathrm{FeOt}$ and $\mathrm{TiO}_{2}$ and decreasing $\mathrm{Al}_{2} \mathrm{O}_{3}$ as $\mathrm{MgO}$ decreases, which imply fractionation along a multiphase cotectic (Fig. 5). Many DZ rocks have high $\mathrm{Al}_{2} \mathrm{O}_{3}$ contents (11-15 wt \%) and Sr contents (250 ppm), and some show positive Eu anomalies on MORB-normalized spidergrams (not shown), implying a plagioclase cumulate component, consistent with plagioclase crystal habits. WUS DZ rocks typically have higher $\mathrm{CaO}(\mathrm{wt} \%)$ and $\mathrm{Sr}(\mathrm{ppm})$ contents than the LPS DZ.

The similarity of igneous stratigraphy, petrography, and major element compositions at the WUS, PS, and LPS indicates very similar differentiation paths of a common (or at least very similar) magma. The most notable difference between the three sills is that the OZ rocks show a systematic shift toward more Fe-rich bulk compositions toward the west (Fig. 5; Table 1), which will be discussed below.

Olivine chemistry

Olivine chemical data (Table 2) provides in situ compositional constraints on the crystals and melts involved in the formation of $\mathrm{OZ}$ rocks in the FCSC. An array of different 


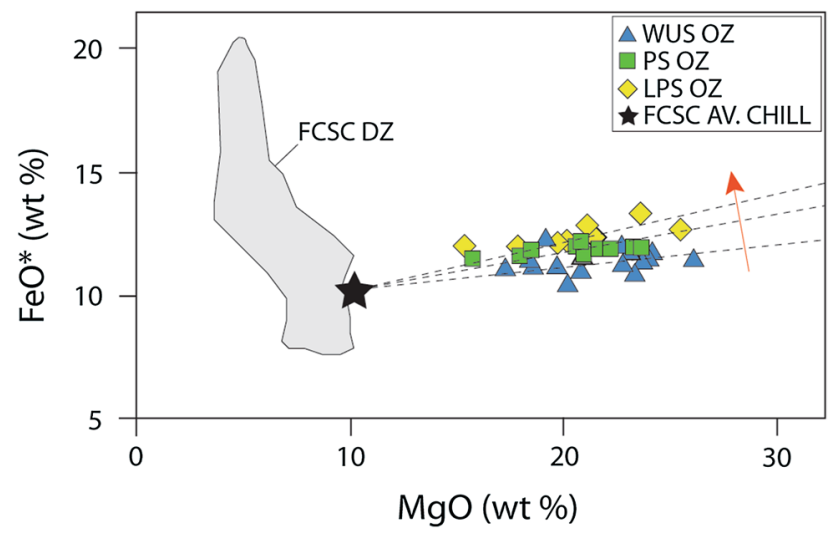

Fig. 5 Bulk-rock $\mathrm{FeO}^{*}$ versus $\mathrm{MgO}$ diagram. The FCSC OZ arrays extend toward $\mathrm{MgO}$-enrichment as well as rotating toward more FeO* compositions (shown by the arrow). The FCSC DZs extend toward $\mathrm{FeO}^{*}$ enrichment, with decreasing $\mathrm{MgO}$. The dashed lines are least square regression fits to the WUS, PS, and LPS OZ arrays that are forced through the average FCSC chill (Table 1). $\mathrm{FeO}^{*}$ has been recalculated from total $\mathrm{Fe}$, with the proportion of $\mathrm{Fe}^{2+}$ to $\mathrm{Fe}^{3+}$ set at 0.9

olivines can be recognized in the FCSC OZ, and we will show that there is a linkage between the morphology, composition, and style of zonation. The chemistry and zonation of olivine within the LPS OZ was described in detail by Hayes et al. (2015), and we summarize those findings here before comparing them to the PS and WUS.

Five different types of olivine morphologies were observed within the LPS OZ, each with a particular range of forsterite $\left(\right.$ molar $\left.\mathrm{Fo}=100 \times \mathrm{Mg} /\left[\mathrm{Mg}+\mathrm{Fe}^{2+}\right]\right)$ content and distinctive core-to-rim zoning styles. Euhedral olivine primocrysts in the LPS lower OZ are the most primitive, with core compositions ranging between $\mathrm{Fo}_{88-82}$. These olivine primocrysts have narrow $\mathrm{Fe}$-rich rims $\left(\mathrm{Fo}_{75}\right)$. This group of primitive olivine primocrysts was interpreted to have been carried as suspended "phenocrysts" in a late olivine slurry replenishment (Hayes et al. 2015), with the Ferich rims recording post-emplacement in situ differentiation of the melt. Euhedral-subhedral chadacrystic olivines that are enclosed by clinopyroxene oikocrysts are more evolved than the primocrysts and have a restricted range of composition, between $\mathrm{Fo}_{83-81}$. Although many are normally zoned, some olivine chadacrysts show reverse zoning. The crystallization of clinopyroxene oikocrysts must therefore postdate the origin of this reverse or normal olivine zoning. Groundmass olivines are similar in size and shape to chadacrysts enclosed by clinopyroxene oikocrysts but are more evolved $\left(\mathrm{Fo}_{81-72}\right)$. Groundmass olivines are typically normally zoned, but some also show reverse zoning. The hopper olivines of the LPS upper OZ have similar compositional ranges $\left(\mathrm{FO}_{80-73}\right)$ to groundmass olivines. Hopper olivines commonly exhibit reverse zoning with the most primitive rim compositions reaching $\mathrm{Fo}_{80}$ in the LPS upper OZ.

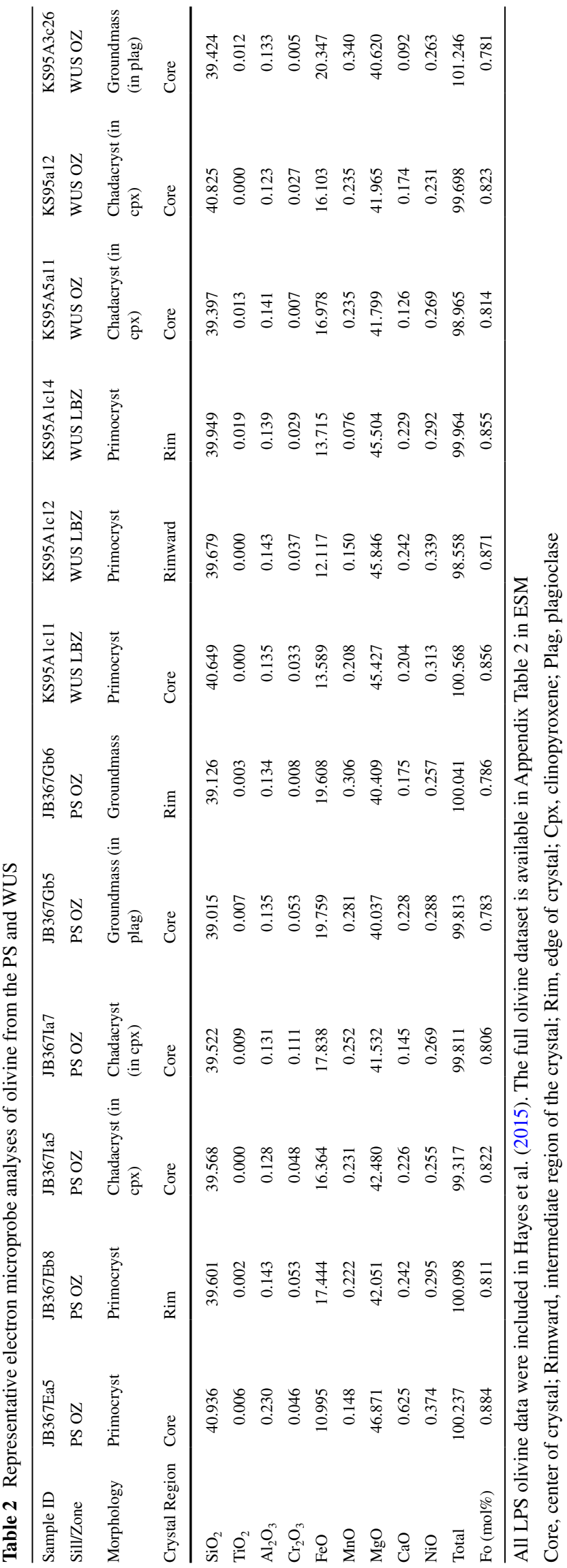


Olivine primocrysts are also common in the WUS $\mathrm{OZ}$ and $\mathrm{PS} \mathrm{OZ}$, with core compositions up to $\mathrm{Fo}_{90}$ being observed at the PS. Olivine chadacrysts enclosed by clinopyroxene oikocrysts have $\mathrm{Fo}_{83-78}$ compositions, similar to the LPS range. Groundmass olivines at the WUS and PS range to lower Fo contents $\left(\mathrm{Fo}_{80-77}\right.$ and $\mathrm{Fo}_{83-68}$, respectively). The Fo contents of hopper olivines at the WUS and PS sites are very similar to those of the LPS OZ, but at the WUS and PS, they are mostly normally zoned.

\section{$\mathrm{Pb}$ - and S-isotopes}

Discrimination plots of ${ }^{208} \mathrm{~Pb} /{ }^{204} \mathrm{~Pb}$ versus ${ }^{206} \mathrm{~Pb} /{ }^{204} \mathrm{~Pb}$ and ${ }^{207} \mathrm{~Pb} /{ }^{204} \mathrm{~Pb}$ versus ${ }^{206} \mathrm{~Pb} /{ }^{204} \mathrm{~Pb}$ are presented in Fig. 6. The WUS and LPS are plotted (we do not have $\mathrm{Pb}$-isotope data for the PS), along with other olivine-enriched sills (Kat's, Dick's, and Uwe's) from the Minto Inlier, some of which may be correlative with the FCSC. The WUS OZ and DZ are close to isotopic equilibrium in both $\mathrm{Pb}$-isotope plots, consistent with derivation from the same magma. In contrast, the LPS OZ and DZ are isotopically distinct in both $\mathrm{Pb}$-isotope plots, indicating that these layers were derived from discrete magmas. This observation supports the replenishment model developed in Hayes et al. (2015). Dick's and Uwe's OZ and DZ are also in Pb-isotope disequilibrium, indicating these are also composite sills. Kat's sill ( $\sim 5 \mathrm{~km}$ SE of the LPS: Fig. 1) may be an offshoot of the FCSC as it is also located just above the Fort Collinson Formation. Isotopically, Kat's sill is similar to the WUS, with an OZ and DZ that are in approximate isotopic equilibrium.

S-isotope data for the PS and LPS are presented in Fig. 7 and Table 3. The PS and LPS exhibit similar $\delta^{34}$ S profiles, with contrasting ranges for their $\mathrm{OZ}$ and $\mathrm{DZ}$ rocks. The LPS exhibits more of a "step-change" between OZ and DZ. In general, OZ rocks have $\delta^{34} \mathrm{~S}$ values ranging between +3 and $+5 \%$, while the DZ rocks have a greater range in $\delta^{34} \mathrm{~S}$ values between +3 and $+8 \%$. The apparent decoupling between the $\mathrm{OZ}$ and $\mathrm{DZ}$ shown by the $\mathrm{S}$-isotopes is consistent with the $\mathrm{Pb}$-isotope disequilibrium observed in the LPS. Values of +3 to $+4 \%$ are common for the Franklin magmas and are suggestive of a slightly anomalous melt source composition (Hryciuk et al. submitted), whereas the range to higher ${ }^{34} \mathrm{~S}$ seen in the DZ rocks suggests these facies incorporated a sedimentary crustal component.

\section{Discussion}

Are the three FCSC sills a single, composite sill?

The WUS, PS, and LPS are all exposed at the same stratigraphic horizon, immediately above the upper contact of

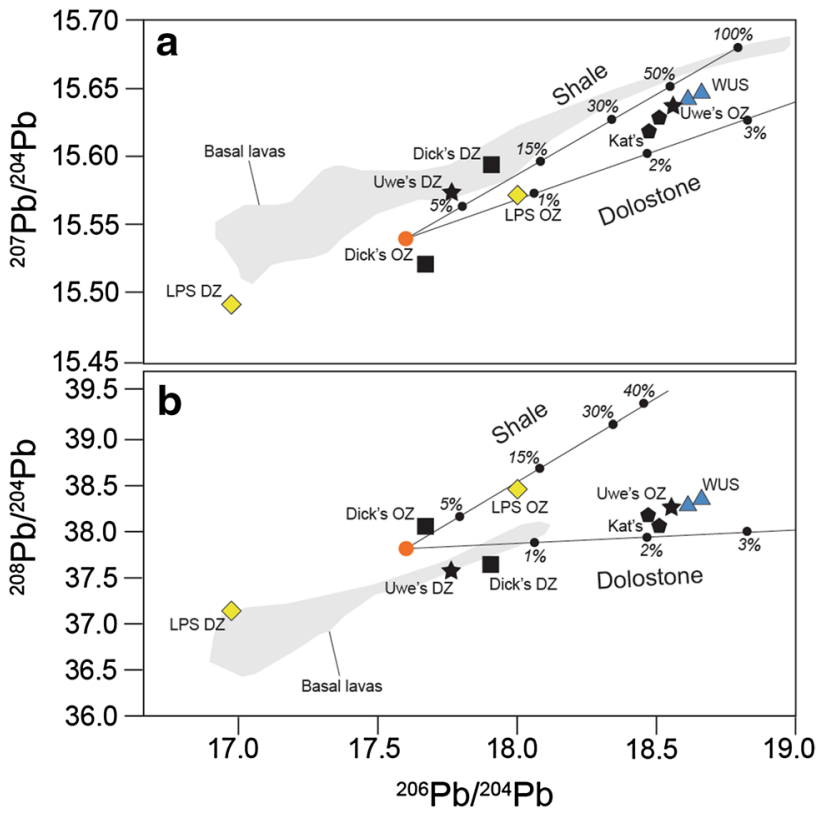

Fig. $6 \mathrm{~Pb}$-isotope discrimination plots with $\mathrm{OZ}$ and $\mathrm{DZ}$ rocks of the FCSC shown, along with other possibly correlative sills (Dick's, Kat's, and Uwe's). a ${ }^{207} \mathrm{~Pb} /{ }^{204} \mathrm{~Pb}$ versus ${ }^{206} \mathrm{~Pb} /{ }^{204} \mathrm{~Pb}$ and b ${ }^{208} \mathrm{~Pb} /{ }^{204} \mathrm{~Pb}$ versus ${ }^{206} \mathrm{~Pb} /{ }^{204} \mathrm{~Pb}$. The compositional field of the basal lava unit of the Natkusiak flood basalts is plotted (gray field) showing $\mathrm{Pb}$-isotope compositions that partly overlap with those of the Type- 1 olivineenriched Franklin sills. Assimilation trajectories for dolostone and shale are shown with the starting composition (red circle) set as the average Type-1 Franklin magma composition

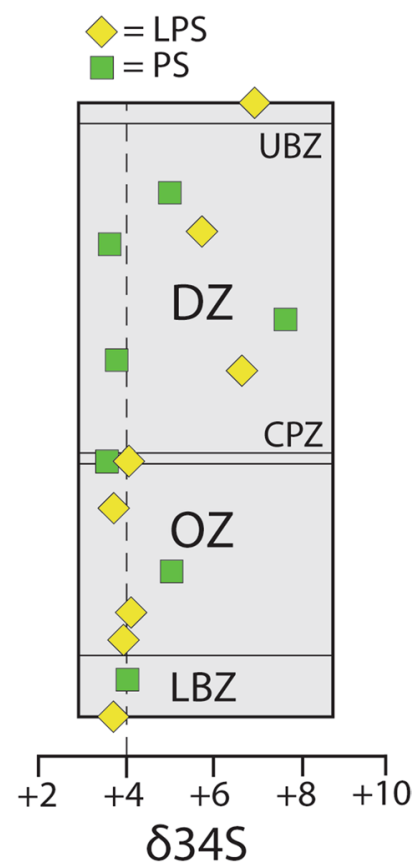

Fig. 7 S-isotope values for the PS and LPS. The stratigraphic log thickness has been normalized in order to compare the data from the two sills 
Table 3 S-isotope data for the LPS and PS

\begin{tabular}{lllll}
\hline Sample ID & Sill & Zone & Height from base (m) & $\delta 34$ (VCDT) \\
\hline 10BH166A1 & LPS & LCM & 0 & 3.69 \\
10BH166A5 & LPS & OZ & 2.72 & 3.96 \\
10BH167A2 & LPS & OZ & 3.64 & 4.1 \\
10BH167A4 & LPS & OZ & 7.28 & 3.72 \\
10BH167A5 & LPS & CPZ & 8.97 & 4.07 \\
10BH167A8 & LPS & DZ & 12.07 & 6.66 \\
10BH167A11 & LPS & DZ & 16.88 & 5.73 \\
11BH311B8 & LPS & UCM & 21.43 & 6.94 \\
10JB287A1 & PS & LCM & 0 & 5.79 \\
10JB367A1 & PS & LBZ & 3 & 3.77 \\
10JB367E1 & PS & LBZ & 4 & 4.84 \\
10JB367G1 & PS & OZ & 7 & 3.27 \\
10JB368B1 & PS & OZ & 9 & 3.57 \\
10JB368D1 & PS & DZ & 12 & 8.02 \\
10JB368G1 & PS & DZ & 16 & 3.53 \\
10JB369A1 & PS & DZ & 18 & 5.12 \\
\hline
\end{tabular}

VCDT Vienna Canyon Diablo Troilite

the Fort Collinson Formation marker unit. They share a similar internal stratigraphy with analogous first-order bimodal layering (OZ/DZ) with comparable petrographic features (Fig. 4), chilled margin compositions (Table 1), and olivine compositions (Table 2). Additionally, the LPS and PS show a roughly similar split between the S-isotope signatures of the OZ versus the DZ (Fig. 7). Dykes at the UM branch toward the west [see Fig. 6 in Bédard et al. (2012)], suggesting westward sill propagation. The thickness of the $\mathrm{OZ}$ decreases systematically from $12 \mathrm{~m}$ at the WUS to $7 \mathrm{~m}$ at the LPS, as does the total sill thickness from $40 \mathrm{~m}$ at the WUS to $20 \mathrm{~m}$ at the LPS. These relationships suggest that the WUS, PS, and LPS represent a single, laterally extensive sill $(>50 \mathrm{~km})$ that propagated westward from a feeder zone at the UM. Hayes et al. (2015) presented mineral-chemical and textural data, indicating that the LPS OZ is a hybrid rock that was produced when a primitive olivine slurry was emplaced into a resident gabbroic mush. The OZ at the PS and WUS shows similar textural characteristics and olivine compositions to those observed in the LPS OZ, and we infer from this that they formed in a similar manner. S-isotope data (Fig. 7) support the distinct origins of the $\mathrm{OZ}$ and $\mathrm{DZ}$ and seem to preclude a simple fractional crystallization relationship between the two layers at the PS and LPS.

$\mathrm{Pb}$-isotopic compositions support the conclusion from S-isotopes that the LPS OZ and DZ originated from different magmas (Fig. 6). Upstream at the WUS, the DZ and $\mathrm{OZ}$ are close to $\mathrm{Pb}-, \mathrm{Sr}-, \mathrm{Nd}-$, and Hf-isotopic equilibrium and have similar trace-element compositions, (Beard et al. submitted). Therefore, the OZ-DZ couple at the WUS appears to have developed by internal differentiation of the same magma. Despite these chemical similarities, the two facies of the WUS are very different in terms of S-isotopic compositions (unpublished data). We suggest that the magmas at the WUS either experienced open-system processes with an extremely heterogeneous host stratigraphy as they migrated through the crust, or that magmas originated in an extremely heterogeneous source mantle and were not homogenized en route, or both. Thus, the LPS OZ magma acquired radiogenic isotope signatures that are distinct from those in the LPS DZ and which also differ from those in the WUS. We will now examine the $\mathrm{Fe}-\mathrm{Mg}$ systematics of the FCSC, so as to determine the compositions of crystals and melts involved in intra-sill differentiation. We will reconsider the isotopic constraints afterward when we develop the FCSC emplacement model.

Crystal-melt Fe-Mg constraints: a heterogeneous olivine crystal cargo?

The $\mathrm{Fe}-\mathrm{Mg}$ relationships help us to constrain the composition of crystals and melt involved in the formation and differentiation of the sills constituting the FCSC. Figure 8 shows the average FCSC chill composition, together with analyses of DZ and OZ rocks from the FCSC sills we have sampled. We have also plotted the LLD pathway predicted from PELE (Boudreau 1999) for the average FCSC chill composition and labeled the point where plagioclase and clinopyroxene join olivine $\left(\mathrm{Fo}_{84}\right)$ on the liquidus. This model LLD pathway overlaps the compositions of DZ rocks from the FCSC, supporting the notion that these DZ rocks are cotectic precipitates derived from fractional crystallization of a tholeiitic melt similar to the average FCSC chill composition.

The petrography (Fig. 4) and $\mathrm{MgO}$-enrichment trends of the FCSC OZ rocks imply olivine accumulation; yet, the $\mathrm{OZ}$ arrays in the FCSC sills (WUS, PS, and LPS) define three distinct trends (Fig. 5). In principle, each individual OZ bulk-rock analysis should represent a two-component mixture of cumulus olivine and trapped melt, now mostly represented by clinopyroxene and plagioclase. The modal proportion of olivine in these rocks ranges between 20 and $55 \%$ (Fig. 8), of which most is indeed "cumulus" textured. A least squares regression trend was fitted to each $\mathrm{OZ}$ array, defining both the composition of (bulk) olivine that accumulated from the melt (Cawthorn et al. 1992) and the composition of the dominant entrapped basaltic melt (Fig. 8). The WUS OZ array intersects the average FCSC chill composition (10.3 wt\% $\mathrm{MgO}$ ) and projects toward an olivine composition of $\mathrm{Fo}_{87}$. The PS OZ array projects toward a more evolved basaltic melt composition (9 wt\% $\mathrm{MgO}$ ) and a more evolved olivine composition of $\mathrm{Fo}_{86}$. The 
Fig. 8 FeO*-MgO systematics of the FCSC with bulk-rock compositional fields as well as the constraints provided by the olivine compositional data and their inverse melt compositions. The histogram attached to the olivine Fo-Fa join shows the distribution of primocrystic, chadacrystic, and groundmass olivine compositions observed in the FCSC OZ from all three sills belonging to the FCSC

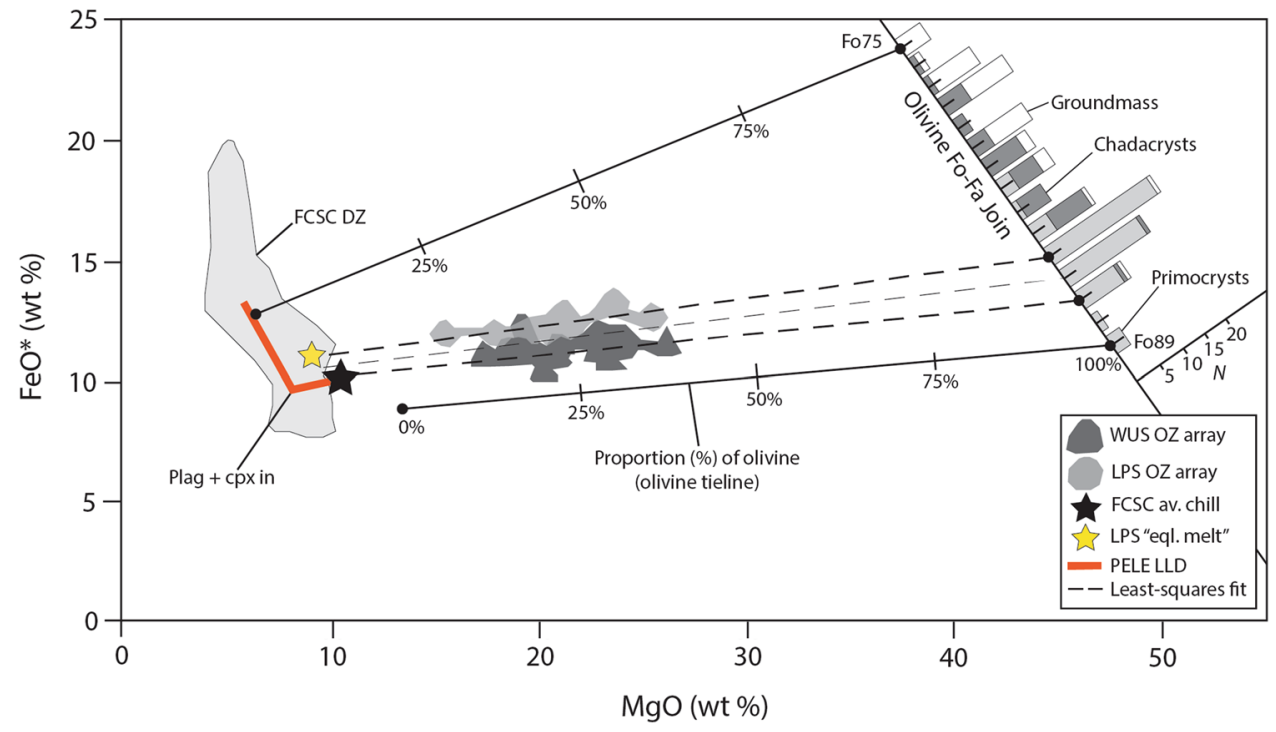

LPS OZ array projects toward a still more evolved basaltic melt composition ( $8 \mathrm{wt} \% \mathrm{MgO}$ ) and a still more evolved olivine composition of $\mathrm{Fo}_{85}$. If we force the regression of the LPS OZ through the average FCSC chill composition (shown in Fig. 5), then the bulk-extract olivine compositions that are required to satisfy the bulk-rock mass balance for the PS and LPS OZ rocks are much more Fe-rich $\left(\sim \mathrm{Fo}_{83}\right)$ than the dominant primocrystic olivines $\left(\sim \mathrm{Fo}_{86}\right)$ that these rocks contain. Although the bulk-rock $\mathrm{Fe}-\mathrm{Mg}$ systematics imply that the olivine cumulates in the FCSC were derived from increasingly more Fe-rich melts toward the west, the observed compositions of olivine in these rocks do not show systematic Fe-enrichment toward the west and only approximately match the required crystal "cumulates" (Fig. 8; Table 2). Clearly, the diversity of olivine compositions (histograms on the Fo-Fa join: Fig. 8) observed within each sill's OZ does not fit an idealized equilibrium crystal-extract model (Cawthorn et al. 1992; Wilson 2012) and implies that the OZ cumulate arrays reflect an average cumulate formed from a heterogeneous olivine crystal cargo.

Can progressive magma fractionation explain the along-strike Fe-enrichment trend?

The westward Fe-enrichment trend in the FCSC OZ (Fig. 5) could perhaps be interpreted as a result of olivine fractionation during flow. However, the data show that olivine primocrysts and chadacrysts have almost identical compositions in the three OZ sections (Table 2). The absence of a systematic trend toward more evolved olivine compositions toward the western end of the FCSC OZ is inconsistent with a simple syn-flow fractional crystallization hypothesis. The $\mathrm{Fe}-\mathrm{Mg}$ systematics imply that the
WUS OZ formed from an accumulation of primitive olivine crystals originating from a melt almost identical in composition to the average FCSC chill composition (Fig. 8). Such a melt $(10.3 \mathrm{wt} \% \mathrm{MgO})$ would be saturated only in olivine (+minor chromite). Therefore, the WUS OZ could plausibly be interpreted to have formed by partial separation of olivine from a melt similar in composition to the average FCSC chill (cf. Cawthorn et al. 1992). In contrast, the LPS OZ array implies the extraction of less forsteritic olivines from a more evolved melt composition (8 wt\% $\mathrm{MgO}$ ), which would have been very close to cosaturation in pyroxene and plagioclase (Fig. 8). Consequently, this melt should not have been able to create a 7-m-thick sequence of olivine cumulates in the LPS, suggesting that the LPS OZ contains "excess" olivine. One might have inferred that the LCM of the LPS (being only $~ 1$ m below the LPS OZ) should have been the melt from which the LPS OZ crystallized. However, the misfit between the entrapped melt composition predicted from the LPS OZ array (Fig. 8) and the LPS LCM (Table 1) implies that the melts from which the LPS OZ was extracted had a different and more complex origin. We will now demonstrate that the along-strike Fe-enrichment trend is best explained by mixing between a late olivine slurry replenishment and a resident gabbroic mush.

Mixing between an olivine slurry and a resident gabbroic mush

Hayes et al. (2015) argued that the LPS OZ is a hybrid rock that formed from a mixture of an evolved component similar in composition to the $\mathrm{DZ}$ and an injected magma charged with olivine. This inference is supported by isotopic data (Figs. 6, 7), which indicate that the LPS OZ and 
DZ are not strictly consanguineous. We will now show that the $\mathrm{OZ}$ in the other sills constituting the FCSC is formed by the same process and then argue that an olivine slurry replenishment propagated $>50 \mathrm{~km}$ in this thin sill. First, we will constrain the compositions of the components involved in mixing, and then, we will quantify their proportions in the mixture, using the $\mathrm{Fe}-\mathrm{Mg}$ diagram.

\section{Component 1: Resident gabbroic mush}

Hayes et al. (2015) argued that the LPS contained a partly crystallized gabbroic mush at the time of olivine slurry replenishment. The composition of the gabbroic mush at this juncture was constrained by comparing the PELE LLD of the average FCSC chill with the melt composition calculated to be in equilibrium with evolved olivine cores located in the LPS OZ. These cores were interpreted to be xenocrystic, being derived from the host gabbro mush. In fact, the composition of evolved xenocrystic olivine cores is very similar across the $\mathrm{FCSC}$, ranging between $\mathrm{Fo}_{77-75}$. Hayes et al. (2015) calculated from Fe-Mg olivine-melt equilibria that these olivine xenocrysts were in equilibrium with melts of $\sim 6 \mathrm{wt} \% \mathrm{MgO}$. The LLD for fractional crystallization of the average FCSC chill is plotted on Fig. 8. At $6 \mathrm{wt} \% \mathrm{MgO}$, the PELE model predicts that $40 \%$ of the melt has solidified, containing $11 \%$ olivine, $16 \%$ plagioclase, and $13 \%$ clinopyroxene. The location of this resident mush mixing pole is labeled as Gab75, and it lies approximately in the middle of the FCSC DZ compositional field (Fig. 9a, b). Olivine cores as evolved as $\mathrm{Fo}_{73}$ are present in the LPS upper OZ, suggesting that more evolved gabbroic material was ingested, and we label this more evolved resident mush as Gab73 (Fig. 9c). We also define a third possible resident mush mixing pole that would correspond to the most evolved possible FCSC DZ compositions as SdH (Sandwich Horizon: Fig. 9c).

\section{Component 2: Olivine slurry}

The olivine primocrysts $\left(\mathrm{Fo}_{88-82}\right)$ in the LPS OZ were interpreted to have been derived from an olivine slurry that was injected into an evolved resident gabbroic mush Hayes et al. (2015). The WUS OZ array links the average FCSC chill composition to olivine compositions $\left(\mathrm{Fo}_{87}\right)$ that are similar to the olivine primocrysts found within these rocks. Therefore, the WUS OZ appears to represent a mixture of a melt similar to the average FCSC chill and forsteritic olivine. In order to be mobile, such an olivine slurry must have contained at least $50 \%$ melt (Marsh 1981; Paterson 2009); so it seems plausible to suggest that the lower-MgO, melt-rich part of the WUS OZ may approximate the olivine slurry-mixing component. We use the average WUS OZ composition (OS87a: Fig. 9a) as one potential olivine slurry-mixing pole. This composition (OS87a) corresponds to $20 \%$ olivine $\left(\mathrm{Fo}_{87}\right)$ in a primitive carrier melt $(13 \mathrm{wt} \%$ $\mathrm{MgO}$ ). The composition of this primitive carrier melt was determined by calculating the melt in equilibrium with $\mathrm{Fo}_{87}$ olivine using the $\mathrm{Fe}=\mathrm{Mg}$ olivine-melt exchange coefficient $(\mathrm{Kd}=0.34)$ of Matzen et al. (2011) with all $\mathrm{Fe}$ as $\mathrm{FeO}$. This calculated carrier melt is more primitive than the FCSC chill, indicating that the melts in equilibrium with this olivine were unfractionated and that the melt at the end of the WUS OZ array defined in Fig. 8 is not in equilibrium with the projected olivine composition. However, given the large spread of olivine primocryst compositions in the FCSC OZ (Fig. 8), it is likely that the olivine slurry was compositionally heterogeneous. The median of olivine primocryst core compositions from the FCSC OZ is $\mathrm{Fo}_{86}$ (see histograms on Fig. 8). This second potential olivine slurrymixing pole (OS86a: Fig. 9b, c) would contain $30 \%$ olivine $\left(\mathrm{Fo}_{86}\right)$ and a carrier melt with $12 \mathrm{wt} \% \mathrm{MgO}$, also calculated using the olivine-melt $\mathrm{Fe}=\mathrm{Mg}$ exchange coefficient of Matzen et al. (2011). More olivine-rich slurry-mixing poles can also be defined. One, which contains $45 \%$ olivine, is on the WUS array (OS87b) and another with $55 \%$ olivine is on the $\mathrm{Fo}_{86}$ tieline (OS86b: Fig. 9c).

\section{Mixing calculations}

Mixing the Gab75 and OS87a components in a proportion of 70:30 creates a hybrid olivine-charged magma that falls on the LPS OZ array (Fig. 9a). Mass balance implies that this hybrid magma would contain $\sim 15 \%$ olivine primocrysts, primarily inherited from the OS87a component, and would have bulk $\mathrm{MgO}$ values between $\sim 15$ and $17 \mathrm{wt} \%$. These hybrid magmas could then unmix to generate the LPS OZ array. Such olivine/liquid unmixing was argued to play an important role in the development of the LPS OZ (Hayes et al. 2015). The same mixing line (Fig. 9a) passes through the PS OZ array, suggesting that the PS OZ might have formed in the same way with a slightly $(\sim 5 \%)$ higher proportion of olivine slurry in the mixture. This pattern is consistent for the PS OZ in all the mixing calculations presented below. It is possible to produce a more $\mathrm{MgO}$-rich 1-stage hybrid that could match the more olivine-rich facies of the OZ (19-21 wt\% MgO or lower OZ). To do so, the olivine slurry would need to contain a higher proportion of olivine (e.g., OS87b). Mixing OS87b (containing 45-50\% olivine), with Gab75, can potentially produce these more MgO-rich compositions as one event, without the need for post-hybridization unmixing (Fig. 9a).

Mixing Gab75 with the OS86a mixing pole in a proportion of 75:25 also generates a more MgO-rich hybrid (Fig. 9b). Mass balance implies that this hybrid magma would contain 20-25\% olivine primocrysts, primarily inherited from the OS86a component, and would have bulk 
Fig. 9 Various $\mathrm{FeO}-\mathrm{MgO}$ mixing models using different mixing poles. a OS87a containing $\sim 20 \%$ olivine $\left(\mathrm{Fo}_{87}\right)$ mixed with Gab75 (with $\sim 6$ wt\% $\mathrm{MgO}$ ), and OS87b containing $\sim 45 \%$ olivine $\left(\mathrm{Fo}_{87}\right)$ mixed with Gab75. b OS86a containing $40 \%$ olivine $\left(\mathrm{Fo}_{86}\right)$ mixed with Gab75, and OS87b with $>50 \%$ olivine $\left(\mathrm{Fo}_{86}\right)$ mixed with Gab75. c OS87a mixed with Gab73 (with $\sim 5$ wt $\%$ $\mathrm{MgO}$ ) and $\mathrm{OS} 87 \mathrm{~b}$ mixed with $\mathrm{SdH}$ (with 4 wt\% MgO)

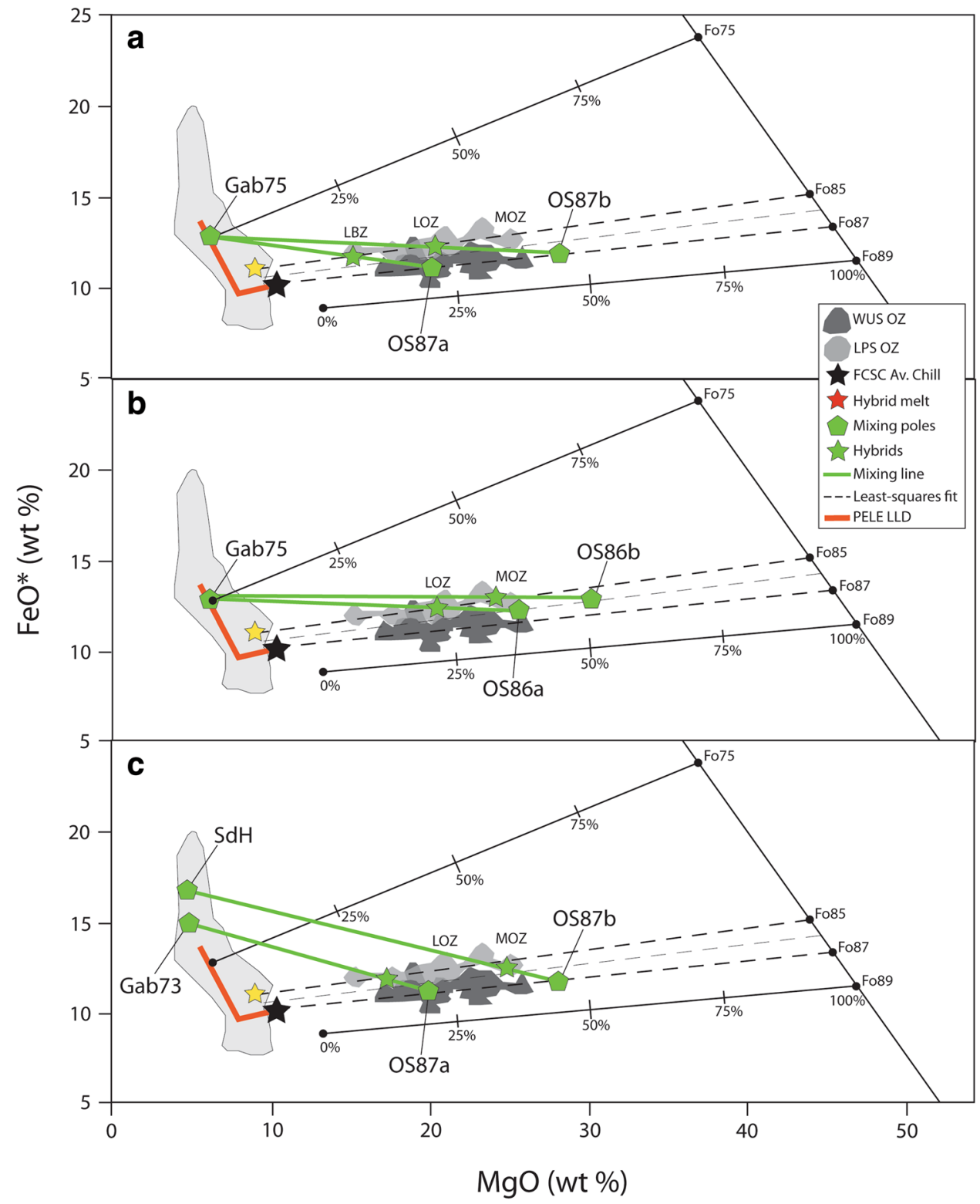

$\mathrm{MgO}$ values between $\sim 19$ and $21 \mathrm{wt} \%$. The most bulk$\mathrm{MgO}$-rich $\mathrm{OZ}$ compositions along the LPS array contain up to $25 \mathrm{wt} \% \mathrm{MgO}$. The more $\mathrm{MgO}$-rich hybrid magmas defined above could have unmixed to produce these higher $\mathrm{MgO}$ bulk-rock compositions. On the other hand, if the high-MgO compositions were formed in one event, then a more olivine-rich slurry would be needed. An 80:20 mix of Gab75 and OS86b (which contains $>50 \%$ olivine) can produce such hybrid magmas. However, we believe this last model is unrealistic because the high proportion of olivine in the slurry would probably inhibit flow and mixing (Marsh 1981; Paterson 2009). Alternatively, instead of high olivine modes in the slurry, the resident gabbroic mush may have been more evolved than Gab75. Mixing Gab73 with OS87a in a proportion of 80:20 can produce hybrid magmas with $\sim 19-21 \mathrm{wt} \% \mathrm{MgO}$ (Fig. 9c). This is a $5 \%$ reduction in the proportion of olivine slurry required, compared to models that use the Gab75 mixing pole.

What these mixing models show is that it is easy to reproduce the more evolved (low $\mathrm{MgO}$ ) part of the LPS $\mathrm{OZ}$ array by some variant of this mixing process, but that it is difficult to generate the more primitive parts of the LPS OZ array (e.g., LPS middle OZ with $\sim 25 \mathrm{wt} \% \mathrm{MgO}$ ) by a 1-stage mixing process unless a very high proportion $(>50 \%)$ of olivine is present in the recharging olivine slurry (e.g., OS86b). If we only consider "reasonable" olivine modes in the olivine slurry (e.g., OS87b), then the more primitive part of the LPS OZ array can only be attained in a single stage if the resident gabbroic mush had a SdH composition, with mixtures of 80:20 (SdH/OS87b). 
However, it seems implausible that the invading olivine slurry could have ingested large volumes of solely latestage evolved magmas that only constitute a small $(\sim 5 \%)$ proportion of Type- 1 sills. We therefore favor a scenario whereby the $\mathrm{MgO}$-rich part of the $\mathrm{OZ}$ arrays form when the hybrid magmas unmixed, which we discuss next.

\section{Post-hybridization unmixing and the formation of high-MgO olivine cumulates}

The propagation of a primitive olivine slurry and its hybridization with a resident gabbroic mush can produce hybrid magmas that explain the formation of the FCSC OZ. The apparent westward decrease in the proportion of the olivine-rich component in the mixture from which the different OZs accumulated suggests that the olivine slurry progressively hybridized with an evolved resident gabbroic mush as it migrated through the sill. This progressive hybridization scenario accounts for the downstream bulk Fe-enrichment trend seen in the FCSC OZ. The resultant hybrid magmas would then have unmixed (crystal-liquid separation) to produce the high- $\mathrm{MgO}$ cumulate arrays displayed in Fig. 9. In the LPS, the olivine slurry seems best preserved in the lower OZ, which contains high-Fo primocrystic olivine. We infer that the high- $\mathrm{MgO}$ rocks ( $\sim 25 \mathrm{wt} \% \mathrm{MgO}$ ) from the LPS middle $\mathrm{OZ}$ best preserve the hybridization/unmixing stage. The LPS middle OZ contains the highest olivine modes (Fig. 8) and is predominantly composed of anhedral olivine that is intergrown with clinopyroxene (Fig. 4d, f, h), with only few ( 5 \%) euhedral olivine primocrysts. These LPS middle OZ olivine compositions $\left(\mathrm{Fo}_{83-81}\right)$ are more evolved than the euhedral olivine primocrysts that characterize the olivine slurry. Based on these textural and compositional constraints, Hayes et al. (2015) proposed that the LPS middle $\mathrm{OZ}$ crystallized directly from a hybrid produced as suggested above. To test this scenario, we ran an assimilation-fractional-crystallization (AFC) model in PELE, to see whether the mixing process described above produces "excess" olivine crystallization and so could account for the lower olivine Fo contents and higher olivine modes $(\sim 55 \%)$ and by extension, the higher $\mathrm{MgO}(\sim 25 \mathrm{wt} \%$ $\mathrm{MgO}$ ) contents observed in the LPS middle OZ. We simulated in PELE, an olivine slurry (containing $30 \%$ olivine and $70 \%$ melt) that assimilates a gabbroic mush (corresponding to an average FCSC DZ composition). The output from this model shows that $\sim 5 \%$ more olivine crystallization is produced prior to the cotectic. Olivine Fo contents are also buffered at $\mathrm{Fo}_{82}$, compared to closedsystem models where Fo decreases rapidly with crystallization. These olivine compositions are similar to the composition of olivines observed in the LPS middle OZ. The AFC model results (Appendix Table 3 in ESM) support the hypothesis that the LPS middle OZ rocks are crystallized from a hybrid magma (Fig. 9).

$\mathrm{Pb}$ - and $\mathrm{S}$-isotopic constraints for the petrogenesis of the FCSC

A record of multiple, isotopically distinct magmas in the FCSC

The spread of $\mathrm{Pb}$-isotope compositions indicates that many different magmas were involved in the generation of the olivine-enriched Franklin sills (Fig. 6). The distribution of $\mathrm{Pb}$-isotope compositions can in part be explained by the assimilation of Shaler Supergroup crustal rocks. Because the WUS OZ/DZ have similar trace-element compositions with enriched $\mathrm{Pb}$ concentrations and distinctive radiogenic ${ }^{206} \mathrm{~Pb} /{ }^{204} \mathrm{~Pb}$ and ${ }^{207} \mathrm{~Pb} /{ }^{204} \mathrm{~Pb}$-isotope compositions, we suggest they shared a similar melt source composition and contamination history. What is pertinent here is that the LPS $\mathrm{OZ}$ and LPS DZ have different $\mathrm{Pb}$ - and $\mathrm{S}$-isotope signatures (Fig. 6), consistent with the composite intrusion model presented in Hayes et al. (2015). In Pb-isotope plots, mixing lines between two geochemical reservoirs are straight lines. As the LPS OZ plots above a tie line between the WUS OZ/ DZ and the LPS DZ, a simple mixture of these two magmas cannot explain its isotopic signature (Fig. 6b), in apparent contradiction with the hybridization model we favor (Fig. 9). If the FCSC does indeed represent a single sill system, then either the olivine slurry replenishment event was internally heterogeneous, or there were two isotopically distinct olivine slurry replenishment events in the FCSC.

We suggest that the igneous rocks preserved at the WUS represent a vigorous late replenishment event, which we suspect pushed previously emplaced magmas downstream toward the LPS. Pb-isotope compositions suggest that relative to the average Type- 1 magma, this final pulse assimilated small amounts $(<10 \%)$ of dolostone (Beard et al. submitted). The Franklin intrusions of the Minto Inlier are hosted by a predominantly carbonate/dolostone sedimentary sequence (Thomson et al. 2014), and calc-silicate reaction products are locally prominent (Nabelek et al. 2013). Bédard et al. (2012) report field and thin-section evidence of dolostone assimilation in the UM. In this context, the gradual shifts in $\mathrm{OZ} \mathrm{Fe} / \mathrm{Mg}$ in the FCSC that we attribute to downstream hybridization (Fig. 9) are superimposed on a secular variation in the geochemical/isotopic signatures of the incoming primitive magmas.

The potential effects of dolostone assimilation on the FCSC magma(s)

As stated above, $\mathrm{Pb}$-isotope variations in the FCSC can be explained by small amounts $(<10 \%)$ of dolostone 


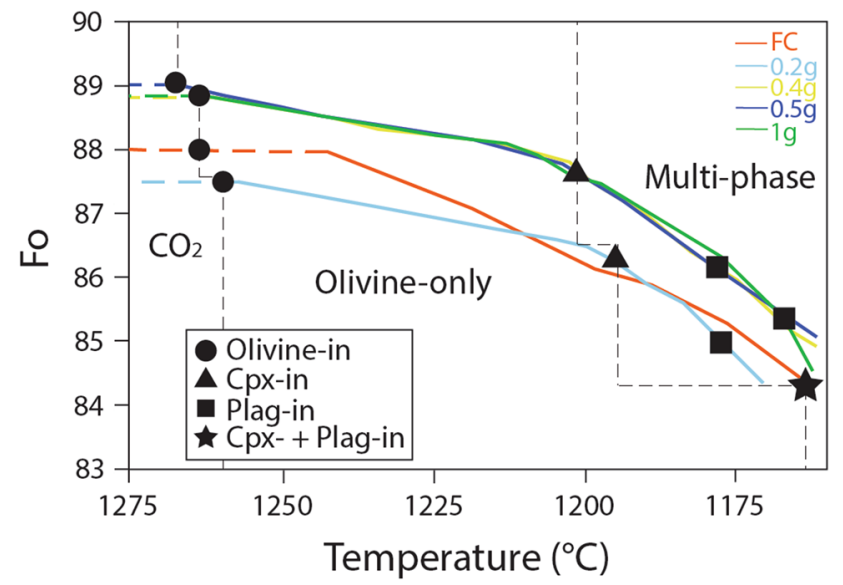

Fig. 10 Forsterite (Fo) in olivine versus temperature diagram showing the LLD of the average FCSC magma during fractional crystallization (FC) and AFC. Dolostone is the contaminant, which has been added to the magma in varying proportions per fractionation step. Models are included in Appendix Table 5 in ESM

assimilation (Beard et al. submitted). We investigated the potential impacts of dolostone assimilation on melt and mineral chemistry using PELE. We used the average FCSC chill as our starting composition (10.3 wt $\%$ $\mathrm{MgO}$ ) and added a dolostone contaminant to the magma $(0.2,0.4,0.5$, and $1 \mathrm{~g}$ of contaminant added per fractionation step). The composition of the contaminant was taken as the average of 26 dolostone bulk-rock analyses from sedimentary rocks of the Minto Inlier (Appendix Table 4 in ESM). The addition of this high-MgO ( 20 wt\%) and low-FeO $(<1 \mathrm{wt} \%)$ dolostone contaminant to the magma has major impacts on the LLD, when compared to regular fractional crystallization. Prior to olivine saturation, abundant $\mathrm{CO}_{2}$ gas is released, and the AFC models with the most dolostone contaminant predict an increase in melt $\mathrm{MgO}$ content up to $11.7 \mathrm{wt} \%$ and decrease the melt $\mathrm{FeO} /$ $\mathrm{MgO}$ ratio. Primitive olivine (up to $\mathrm{Fo}_{89}$ ) crystallizes at temperatures of $\sim 1,260{ }^{\circ} \mathrm{C}$, earlier than in closed-system models for this melt composition (Fig. 10). Between 1,260 and $1,200{ }^{\circ} \mathrm{C}, \sim 7 \%$ olivine crystallizes and $7 \% \mathrm{CO}_{2}$-rich gas is released. In contrast to fractionation models without dolostone assimilation where olivine Fo contents decrease rapidly (Fig. 10), assimilation of $\mathrm{MgO}$-rich dolostone buffers olivine Fo contents at values of $\sim \mathrm{Fo}_{88-87}$ in the 1,260$1,200{ }^{\circ} \mathrm{C}$ interval (Fig. 10). Clinopyroxene begins to crystallize earlier in the dolostone-AFC models compared to the closed-system model due to the high $\mathrm{CaO}$ contents (24-47 wt\%) of the dolostone contaminant, with up to $\sim 20 \%$ clinopyroxene being extracted before the arrival of plagioclase. In contrast, both clinopyroxene and plagioclase join olivine on the liquidus nearly simultaneously in closed-system models.
The modeled effects of dolostone assimilation on the FCSC magma are very similar to those observed experimentally (Iacono Marziano et al. 2008; Mollo and Vona 2014) and resemble products of volcanic systems where assimilation of host carbonates occurred (Chadwick et al. 2007; Di Rocco et al. 2012; Troll et al. 2013). Dolostone assimilation in the FCSC magma could help explain the high-Fo compositions of olivine cores in the WUS OZ. Additionally, the effects of volatile and gas budgets within crystal mushes have been shown to affect their viscosity. $\mathrm{CO}_{2}$ produced from dolostone assimilation may have reduced the viscosity of propagating crystal-rich magmas and thus facilitated hybridization (Pistone et al. 2013).

Differentiation model for the FCSC magmatic plumbing system

The evidence we have presented is consistent with a model whereby the FCSC OZ formed from a late injection of olivine-enriched magma that mixed with a resident, partly consolidated gabbroic mush. This olivine slurry was sourced from upstream in the FCSC, possibly from the UM feeder system. Multiple isotopic signatures are recorded within the FCSC. One potential explanation for this is that the olivine slurry replenishment was internally isotopically heterogeneous upon emplacement. The LPS DZ isotopic signature (Fig. 6) would represent the earliest pulse of magma into the FCSC and seem to record minor amounts of Archean basement or sedimentary rock contamination (Beard et al. submitted). This first event was then injected by an isotopically distinct olivine slurry. The isotopic signature of this second pulse is consistent with small amounts of dolostone assimilation (Fig. 6). In contrast, $\sim 10 \%$ dolostone assimilation appears to best explain the observed $\mathrm{Pb}$-isotope compositions of the last major batch of magma emplaced into the FCSC (Beard et al. submitted) at the WUS (Fig. 6), where magma differentiated into an OZ/DZ couple after emplacement. The simplest explanation for these near-random shifts in radiogenic isotope composition is that they reflect differences in the types of host rock encountered and assimilated in transit. The field evidence suggests to us that contamination mostly occurred during transport of magma through fault-guided conduits populated by cataclastic breccias (Bédard et al. 2012). Even though magmas being injected into the system were isotopically heterogeneous, the extent of contamination was small, such that similar textural and petrological facies were developed at the WUS, PS, and LPS.

Olivine slurry replenishment appears to have been widespread in the Franklin plumbing system, since Type-1 olivine-enriched sills (Kat's, Dick's, and Uwe's sills) are common at the stratigraphic level where the FCSC was 


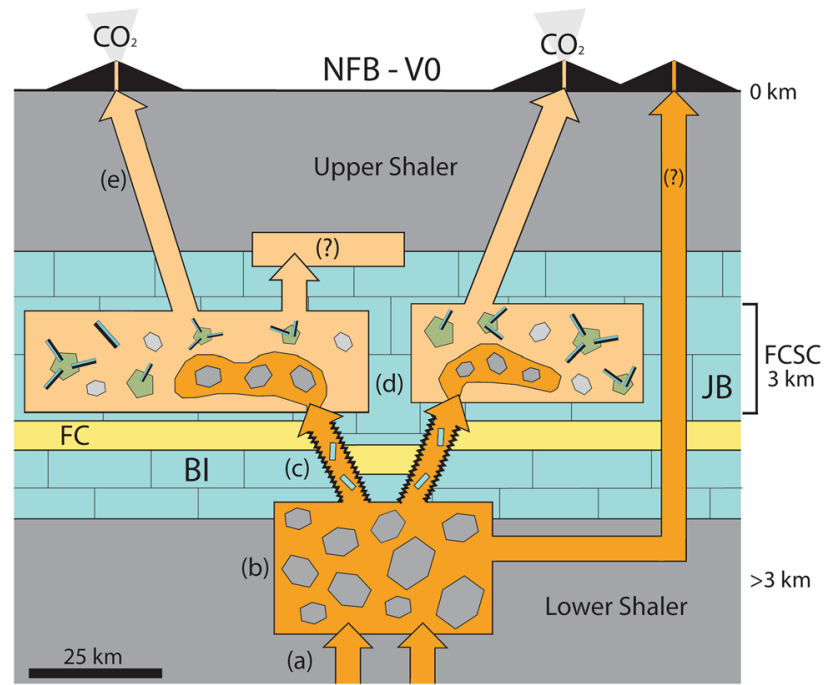

Fig. 11 Schematic diagram illustrating the formation of the FCSC and the basal lava sequence of the Natkusiak flood basalts (NFB). $a$ Deep $(>3 \mathrm{~km}$ ) holding sills or feeder conduits are fed by fresh batches of primitive melt from isotopically distinct mantle sources; $b$ after initial residual magmas escape from the holding system, primitive olivine cumulates with equilibrium melts are left behind, and then are remobilized by melt replenishment events; $c$ remobilized olivine slurries ascend along Neoproterozoic faults (arrows with squiggly contacts), where they assimilate brecciated dolostone; $d$ olivine slurries are emplaced into the FCSC, which already hosts a partly crystallized gabbroic mush derived from an earlier magma pulse; $e$ residual melts to the sills erupt at the surface if structures facilitate melt escape. The erupted melt forms the basal Natkusiak Fm lavas. If melts affected by dolostone assimilation were erupted, then significant quantities of $\mathrm{CO}_{2}$ may have been released from degassing lava. BI Boot Inlet Formation, FC Fort Collinson Formation, $J B$ Jago Bay Formation

emplaced. Kat's sill is similar to the WUS in that it shows isotopic equilibrium between $\mathrm{OZ}$ and $\mathrm{DZ}$, as well as having isotopic signatures very similar to those of the WUS. Kat's sill is located just to the south of the FCSC (Fig. 1) and may represent another branch of the WUS-forming pulse. In contrast, Dick's and Uwe's sills both show OZ/ DZ isotopic disequilibrium. These two sills would record different, non-unique sources and/or differentiation paths. As the OZ of Uwe's sill has similar radiogenic isotope and trace-element ratios to rocks from the WUS and Kat's sill, the magma from which Uwe's OZ accumulated may also have been affected by dolostone assimilation.

We present a model for the development of the FCSC olivine-enriched rocks in Fig. 11. The geochemical effects of olivine slurry replenishment and mixing with a resident gabbroic mush described above have implications for other systems where slurry emplacement has been inferred (e.g., Gibb and Henderson (2006); Bédard et al. (2007); Marsh (2013)). The isotopic constraints imply that the emplacement dynamics of these heterogeneous olivine slurry replenishment events are similar to the "braided sills" differentiation model of the Torres Del Paine Mafic Complex in Patagonia (Leuthold et al. 2014). Our assimilationreplenishment scenario is also analogous to the Roelofse and Ashwal (2012) model proposed for the formation of the Main Zone of the Bushveld Complex. In their model, crustal contamination of crystal mushes occurred in sub-compartments of an underlying feeder system. A similar scenario may have operated beneath the FCSC at $>3 \mathrm{~km}$ depth in the Franklin plumbing system. Olivine slurry replenishment may have also operated in other sills associated with rift-related LIPs, e.g., Palisades sill, Husch (1990), which is part of the Central Atlantic Magmatic Province. Ultimately, our documentation of lateral variations in the compositions of the olivine-enriched sills of the Minto Inlier provides insight into magma/crystal slurry flow directions. These have important implications for the evolution of magmatic plumbing systems, intra-sill mixing, and the search for economic $\mathrm{Ni}-\mathrm{S}$ deposits.

\section{Conclusion}

The FCSC of the Franklin LIP extends for $>50 \mathrm{~km}$ along strike, and its constituent sills are characterized by basal olivine-enriched layers $(\mathrm{OZ})$ and capping gabbros (DZ). We investigated three sections through the FCSC. At its eastern end is the WUS, in the center is the P-sill (PS) and at its western end is the LPS. The FCSC OZ rocks exhibit a gradual westward shift toward more Fe-rich bulk compositions. Olivine cumulate arrays on $\mathrm{Fe}-\mathrm{Mg}$ plots were used to define bulk crystal extracts and equilibrium melts. The predicted equilibrium PS and LPS olivine compositions only approximately match the olivine cargo they contain, however, suggesting excess olivine was added. We propose that the primitive olivine primocrysts within the FCSC OZ were derived from a replenishing olivine slurry, which was emplaced into and mixed with a partly crystalline gabbroic mush. Downstream propagation and hybridization between these two components can explain the westward $\mathrm{Fe}$-enrichment trend in the FCSC OZ. Radiogenic isotope data suggest that there were at least three geochemically distinct pulses of magma in the FCSC. Isotopic signatures in the WUS can be explained by small amounts of dolostone assimilation, which buffers the melt $\mathrm{Mg} / \mathrm{Fe}$ ratio enabling crystallization of the higher-Fo olivine that characterizes the WUS. In addition, clinopyroxene is preferentially stabilized on the liquidus ahead of plagioclase, and significant quantities of $\mathrm{CO}_{2}$ are released during dolostone assimilation. The similarities between the FCSC and other olivine-enriched Franklin sills suggest that olivine slurry replenishment events are common, and that the olivinerich slurries were able to propagate $>50 \mathrm{~km}$ along strike in a thin sill. 
Acknowledgments This study was supported by the Geomapping for Energy and Minerals (GEM) program, led by the Geological Survey of Canada. We greatly acknowledge all of the geologists involved in the mapping of Victoria Island during two summers in 2010 and 2011. Mapping and sampling by everyone involved contributed to the Victoria Island geochemical database. We particularly thank Dick Naslund and Kathryn Steigerwaldt for sampling the WUS section. We also thank Boswell Wing, Matthew Hryciuk, Marc Choquette, Iain McDonald, Ley Wooley, and Tony Oldroyd for their help with sample preparation and data collection. Comments by John Maclennan and Michel Houlé improved earlier versions. We are grateful for the thoughtful reviews of Othmar Müntener, Bruce Marsh, and an anonymous reviewer. Hayes was supported by a Natural Environment Research Centre (NERC) research studentship (Grant Number NE/152787X/1). This is NRCAN/ESS contribution 20140231.

Open Access This article is distributed under the terms of the Creative Commons Attribution License which permits any use, distribution, and reproduction in any medium, provided the original author(s) and the source are credited.

\section{References}

Ariskin AA, Konnikov EG, Danyushevsky LV, Kislov EV, Nikolaev GS, Orsoev DA, Barmina GS, Bychkov KA (2009) The Dovyren intrusive complex: problems of petrology and $\mathrm{Ni}$ sulfide mineralization. Geochem Int 47(5):425-453

Baragar WRA (1976) The Natkusiak basalts, Victoria Island, District of Franklin; in report of activities, part A. Geological Survey of Canada Paper 76-1A:347-352

Bédard JH (1991) Cumulate recycling and crustal evolution in the Bay of Islands ophiolite. J Geol 99:225-249

Bédard JHJ, Marsh BD, Hersum TG, Naslund HR, Mukasa SB (2007) Large-scale mechanical redistribution of orthopyroxene and plagioclase in the basement sill, ferrar dolerites, mcmurdo dry valleys, Antarctica: petrological, mineral-chemical and field evidence for channelized movement of crystals and melt. J Petrol 48(12):2289-2326

Bédard JH, Leclerc F, Harris LB, Goulet N (2009) Intra-sill magmatic evolution in the Cummings Complex, Abitibi greenstone belt: Tholeiitic to calc-alkaline magmatism recorded in an Archaean subvolcanic conduit system. Lithos 111(1-2):47-71

Bédard JH, Naslund HR, Nabelek P, Winpenny A, Hryciuk M, Macdonald W, Hayes B, Steigerwaldt K, Hadlari T, Rainbird R, Dewing K, Girard É (2012) Fault-mediated melt ascent in a Neoproterozoic continental flood basalt province, the Franklin sills, Victoria Island, Canada. Geol Soc Am Bull 124(5-6):723-736

Boudreau AE (1999) PELE-a version of the MELTS software program for the PC platform. Comput Geosci 25(2):201-203

Bowen NL (1928) The evolution of igneous rocks. Princeton University, Princeton

Cawthorn RG, Sander BK, Jones IM (1992) Evidence for the trapped liquid shift effect in the Mount Ayliff Intrusion, South Africa. Contrib Mineral Petrol 111(2):194-202

Chadwick JP, Troll VR, Ginibre C, Morgan D, Gertisser R, Waight TE, Davidson JP (2007) Carbonate assimilation at Merapi Volcano, Java, Indonesia: insights from crystal isotope stratigraphy. J Petrol 48(9):1793-1812

Chevallier L, Woodford A (1999) Morph-tectonics and mechanism of emplacement of the dolerite rings and sills of the western Karoo, South Africa. S Afr J Geol 102:43-54

Denyszyn SW, Halls HC, Davis DW, Evans DAD (2009) Paleomagnetism and U-Pb geochronology of Franklin dykes in High
Arctic Canada and Greenland: a revised age and paleomagnetic pole constraining block rotations in the Nares Strait region. Can J Earth Sci 46(9):689-705

Di Rocco T, Freda C, Gaeta M, Mollo S, Dallai L (2012) Magma chambers emplaced in carbonate substrate: petrogenesis of skarn and cumulate rocks and implications for $\mathrm{CO}_{2}$ degassing in volcanic areas. J Petrol 53(11):2307-2332

Dostal J, Baragar WRA, Dupuy C (1986) Petrogenesis of the Natkusiak continental basalts, Victoria Island, Northwest Territories, Canada. Can J Earth Sci 23:622-632

Ernst RE, Wingate MTD, Buchan KL, Li ZX (2008) Global record of 1600-700 Ma Large Igneous Provinces (LIPs): implications for the reconstruction of the proposed Nuna (Columbia) and Rodinia supercontinents. Precambrian Res 160(1-2):159-178

Francis EH, Walker BH (1986) Emplacement of alkali-dolerite sills relative to extrusive volcanism and sedimentary basins in the Carboniferous of Fife, Scotland. Trans Roy Soc Edinb 77:309-323

Gaeta M, Di Rocco T, Freda C (2009) Carbonate assimilation in open magmatic systems: the role of melt-bearing skarns and cumulateforming processes. J Petrol 50(2):361-385

Gibb FGF, Henderson CMB (2006) Chemistry of the Shiant Isles Main Sill, NW Scotland, and wider implications for the petrogenesis of mafic sills. J Petrol 47(1):191-230

Hawkesworth CJ, Lightfoot PC, Fedorenko VA, Blake S, Naldrett AJ, Doherty W, Gorbachev NS (1995) Magma differentiation and mineralisation in the Siberian continental flood basalts. Lithos 34(1-3):61-88

Hayes B, Bédard JH, Lissenberg CJ (2015) Olivine slurry replenishment and the development of igneous layering in a Franklin Sill, Victoria Island, Arctic Canada. J Petrol 56(1):83-112

Heaman LM, LeCheminant AN, Rainbird RH (1992) Nature and timing of Franklin igneous events, Canada: implications for a late Proterozoic mantle plume and the break-up of Laurentia. Earth Planet Sci Lett 109(1-2):117-131

Hildreth W, Moorbath S (1988) Crustal contributions to arc magmatism in the Andes of Central Chile. Contrib Mineral Petrol 98(4):455-489

Hulbert L, Rainbird RH, Jefferson CW, Friske P (2005) Map of mafic and ultramafic bodies related to the Franklin Magmatic Event, Minto Inlier, Victoria Island. Geological Survey of Canada OpenFile Map 4928, map scale sheet 1:1,000,000+CD ROM

Husch JM (1990) Palisades sill—origin of the olivine zone by separate magmatic injection rather than gravity settling. Geology 18:699-702

Iacono Marziano G, Gaillard F, Pichavant M (2007) Limestone assimilation and the origin of $\mathrm{CO}_{2}$ emissions at the Alban Hills (Central Italy): constraints from experimental petrology. J Volcanol Geotherm Res 166(2):91-105

Iacono Marziano G, Gaillard F, Pichavant M (2008) Limestone assimilation by basaltic magmas: an experimental re-assessment and application to Italian volcanoes. Contrib Mineral Petrol 155(6):719-738

Irvine TN (1980) Magmatic density currents and cumulus processes. Am J Sci 280A:1-58

Irvine TN (1982) Terminology for layered intrusions. J Petrol 23(2):127-162

Irvine TN (1987) Layering and related structures in the Duke Island and Skaergaard intrusions: similarities, differences, and origins. In: Parsons I (ed) Origins of igneous layering. NATO ASI Series C. Math Phys Sci 196:185-245

Jefferson CW (1977) Stromatolites, sedimentology, and stratigraphy of parts of the Amundsen Basin, N.W.T.. [MS thesis]: London, Ontario, Canada, University of Western Ontario, p 260

Jefferson CW, Hulbert L, Rainbird RH, Hall GEM, Gregoire DC, Grinenko LI (1994) Mineral resource assessment of the Neoproterozoic Franklin igneous events of Arctic Canada: comparison 
with the Permo-Triassic Noril'sk-Talnakh Ni-Cu-PGE deposits of Russia. Geological Survey of Canada Open File Report 2789:48

Kerr AC, Tarney J, Nivia A, Marriner GF, Saunders AD (1998) The internal structure of oceanic plateaus: inferences from obducted Cretaceous terranes in western Colombia and the Caribbean. Tectonophysics 292(3-4):173-188

Larrea P, França Z, Lago M, Widom E, Galé C, Ubide T (2012) Magmatic processes and the role of antecrysts in the genesis of Corvo Island (Azores Archipelago, Portugal). J Petrol 54(4):769-793

Leclerc F, Bédard JH, Harris LB, McNicoll VJ, Goulet N, Roy P, Houle P (2011) Tholeiitic to calc-alkaline cyclic volcanism in the Roy Group, Chibougamau area, Abitibi Greenstone Beltrevised stratigraphy and implications for VHMS explorationGeological Survey of Canada Contribution 20100254. Ministère des Ressources naturelles et de la Faune Contribution 8439-20102011-17. Can J Earth Sci 48(3):661-694

Leuthold J, Müntener O, Baumgartner LP, Putlitz B (2014) Petrological constraints on the recycling of mafic crystal mushes and intrusion of braided sills in the Torres del Paine mafic complex (Patagonia). J Petrol 55(5):917-949

Lissenberg CJ, Bédard JH, van Staal CR (2004) The structure and geochemistry of the gabbro zone of the Annieopsquotch ophiolite, Newfoundland: implications for lower crustal accretion at spreading ridges. Earth Planet Sci Lett 229(1-2):105-123

Macdonald FA, Schmitz MD, Crowley JL, Roots CF, Jones DS, Maloof AC, Strauss JV, Cohen PA, Johnston DT, Schrag DP (2010) Calibrating the cryogenian. Science 327:1241-1243

Marsh BD (1981) On the crystallinity, probability of occurrence, and rheology of lava and magma. Contrib Mineral Petrol 78(1):85-98

Marsh BD (2004) A magmatic mush column rosetta stone: the McMurdo Dry Valleys, Antarctica. EOS Trans Am Geophys Union 85(47):497-508

Marsh BD (2013) On some fundamentals of igneous petrology. Contrib Mineral Petrol 166(3):665-690

Matzen AK, Baker MB, Beckett JR, Stolper EM (2011) Fe-Mg partitioning between olivine and high-magnesian melts and the nature of Hawaiian parental liquids. J Petrol 52(7-8):1243-1263

McDonald I, Viljoen KS (2006) Platinum-group element geochemistry of mantle eclogites: a reconnaissance study of xenoliths from the Orapa kimberlite, Botswana. Appl Earth Sci 115(3):81-93

Mollo S, Vona A (2014) The geochemical evolution of clinopyroxene in the Roman Province: a window on decarbonation from wallrocks to magma. Lithos 192-195:1-7

Mondal SK, Mathez EA (2007) Origin of the UG2 chromitite layer, Bushveld Complex. J Petrol 48(3):495-510

Nabelek PI, Bédard JH, Hryciuk M, Hayes B (2013) Short-duration contact metamorphism of calcareous sedimentary rocks by Neoproterozoic Franklin gabbro sills and dykes on Victoria Island, Canada. J Metamorph Geol 31(2):205-220

Naldrett AJ (1992) A model for the Ni-Cu-PGE ores of the Noril'sk region and its application to other areas of flood basalt. Econ Geol 87:1945-1962

Naslund HR, McBirney AR (1996) Mechanisms of formation of igneous layering. In: Richard Grant C (ed) Developments in petrology, vol 15. Elsevier, Amsterdam, pp 1-43

Neave DA, Passmore E, Maclennan J, Fitton G, Thordarson T (2013) Crystal-melt relationships and the record of deep mixing and crystallization in the ad 1783 Laki Eruption, Iceland. J Petrol 54(8):1661-1690
Passmore E, Maclennan J, Fitton G, Thordarson T (2012) Mush disaggregation in basaltic magma chambers: evidence from the ad 1783 Laki Eruption. J Petrol 53(12):2593-2623

Paterson SR (2009) Magmatic tubes, pipes, troughs, diapirs, and plumes: late-stage convective instabilities resulting in compositional diversity and permeable networks in crystal-rich magmas of the Tuolumne batholith, Sierra Nevada, California. Geosphere $5(6): 496-527$

Pehrsson SJ, Buchan KL (1999) Borden dykes of Baffin Island, Northwest Territories: a Franklin U-Pb baddeleyite age and a paleomagnetic reinterpretation. Can J Earth Sci 36(1):65-73

Pistone M, Caricchi L, Ulmer P, Reusser E, Ardia P (2013) Rheology of volatile-bearing crystal mushes: mobilization vs. viscous death. Chem Geol 345:16-39

Rainbird R (1993) the sedimentary record of mantle plume uplift preceding eruption of the Neoproterozoic Natkusiak flood basalt. J Geol 101:305-318

Rainbird RH, Jefferson CW, Hildebrand RS, Worth JK (1994) The shaler supergroup and revision of Neoproterozoic stratigraphy in Amundsen Basin, Northwest Territories. Geol Surv Can Curr Res A 1994-C:61-70

Rainbird RH, Jefferson CW, Young GM (1996) The early Neoproterozoic sedimentary succession B of northwestern Laurentia: correlations and paleogeographic significance. Geol Soc Am Bull 108(4):454-470

Roelofse F, Ashwal LD (2012) The lower main zone in the Northern Limb of the Bushveld Complex-a $>1.3 \mathrm{~km}$ thick sequence of intruded and variably contaminated crystal mushes. J Petrol 53(7):1449-1476

Shellnutt JG, Dostal J, Keppie JD (2004) Petrogenesis of the $723 \mathrm{Ma}$ Coronation sills, Amundsen basin, Arctic Canada: implications for the break-up of Rodinia. Precambrian Res 129(3-4):309-324

Thomson D, Rainbird RH, Dix G (2014) Architecture of a Neoproterozoic intracratonic carbonate ramp succession: Wynniatt Formation, Amundsen Basin, Arctic Canada. Sediment Geol 299:119-138

Troll VR, Deegan FM, Jolis EM, Harris C, Chadwick JP, Gertisser R, Schwarzkopf LM, Borisova AY, Bindeman IN, Sumarti S, Preece K (2013) Magmatic differentiation processes at Merapi Volcano: inclusion petrology and oxygen isotopes. J Volcanol Geotherm Res 261:38-49

Varfalvy V, Hébert R, Bedard JH, Laflèche MR (1997) Petrology and geochemistry of pyroxenite dykes in upper mantle peridotites of the North Arm Mountain massif, Bay of Islands Ophiolite, Newfoundland: implications for the genesis of boninitic and related magmas. Can Mineral 35(2):543-570

Wager LR, Deer WA (1939) Geological investigations in East Greenland Part III. The petrology of the Skaergaard Intrusion, Kangerdlugssuaq, East Greenland. Meddelelser om Grønland 105:1-352

Wignall PB (2001) Large igneous provinces and mass extinctions. Earth Sci Rev 53(1-2):1-33

Williamson N, Bédard JH, Ootes L, Rainbird R, Cousens B, Zagorevski A (2013) Volcanostratigraphy and significance of the southern lobe Natkusiak Formation flood basalts, Victoria Island, Northwest Territories. Geol Surv Can Curr Res 2013-16:13

Wilson AH (2012) A chill sequence to the Bushveld Complex: insight into the first stage of emplacement and implications for the parental magmas. J Petrol 53(6):1123-1168 